\title{
Revisiting the thiosemicarbazonecopper(II) reaction with glutathione. Activity against colorectal carcinoma cell lines.
}

Javier García-Tojal ${ }^{a}$,*, Rubén Gil-García ${ }^{a}$, Víctor Ivo Fouz ${ }^{a}$, Gotzon Madariaga ${ }^{b}$, Luis Lezama $^{c}$, María S. Galletero ${ }^{d}$, Joaquín Borrás ${ }^{e}$, Friederike I. Nollmann ${ }^{f}$, Carlos GarcíaGirón $^{g}$, Raquel Alcaraz ${ }^{g}$, Mónica Cavia-Saiz ${ }^{h}$, Pilar Muñiz ${ }^{h}$, Òscar Palacios ${ }^{i}$, Katia G. Samper ${ }^{i}$ Teófilo Rojo ${ }^{c, *}$.

${ }^{a}$ Departamento de Química, Universidad de Burgos, 09001 Burgos, Spain

b Departamento de Física de la Materia Condensada, Universidad del País Vasco, Aptdo. 644, 48080 Bilbao, Spain

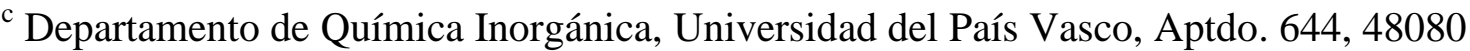
Bilbao, Spain

d Servicio Central de Espectrometria de Masas, Universidad de Valencia, Av. Dr. Moliner 100, Burjassot (Valencia), Spain

e Departamento de Química Inorgánica, Facultad de Farmacia, Universidad de Valencia, 46100, Burjassot (Valencia), Spain

${ }^{\mathrm{f}}$ Merck Stiftungsprofessur für Molekulare Biotechnologie, Fachbereich Biowissenschaften, Goethe Universität Frankfurt, 60438 Frankfurt am Main, Germany ${ }^{g}$ Unidad de Investigación del Hospital Universitario de Burgos, Avda. Islas Baleares 3, 09006 Burgos, Spain

${ }^{\mathrm{h}}$ Departamento de Biotecnología y Ciencia de los Alimentos, Universidad de Burgos, Pza. Misael Bañuelos s/n, 09001 Burgos, Spain

${ }^{\text {i }}$ Departament de Química, Universitat Autònoma de Barcelona, E-08193 Cerdanyola del Vallès, Barcelona, Spain

* Corresponding author: +34 947 258035; Fax:+34 947258831

e-mail address: qipgatoj@ubu.es

Keywords: Colon carcinoma. Copper. Molecular magnetism. Thiosemicarbazone Conflicts of interest: none

\section{Abstract}


Thiosemicarbazones (TSCs), and their copper derivatives, have been extensively studied mainly due to the potential applications as antitumor compounds. A part of the biological activity of the TSC-Cu ${ }^{\mathrm{II}}$ complexes rests on their reactivity against cell reductants, as glutathione (GSH). The present paper describes the structure of the $\left[\mathrm{Cu}(\mathrm{PTSC})\left(\mathrm{ONO}_{2}\right)\right]_{\mathrm{n}} \quad$ compound (1) $\quad$ (HPTSC $\quad=$ pyridine-2-carbaldehyde thiosemicarbazone) and its spectroscopic and magnetic properties. ESI studies performed on the reaction of GSH with 1 and the analogous $\left[\left\{\mathrm{Cu}(\mathrm{PTSC} *)\left(\mathrm{ONO}_{2}\right)\right\}_{2}\right]$ derivative (2, HPTSC* = pyridine-2-carbaldehyde 4N-methylthiosemicarbazone) show the absence of peaks related with TSC-Cu-GSH species. However GSH-Cu ones are detected, in good agreement with the release of $\mathrm{Cu}^{\mathrm{I}}$ ions after reduction in the experimental conditions. The reactivity of 1 and 2 with cytochrome c and myoglobin and their activities against HT-29 and SW-480 colon carcinoma cell lines are compared with those shown by the free HPTSC and HPTSC* ligands.

\section{1.- Introduction}

Thiosemicarbazones (TSCs) are sulfur-containing organic substances whose biological properties have been extensively studied [1-8], in particular their activities against microbial diseases as malaria, small-pot, influenza, leishmaniasis or chagas [914], neurological pathologies $[15,16]$ and cancer $[17-36]$. Different biological targets have been identified, like DNA [37-39], RNA [40] and several enzymes as RNA-dependent DNA polymerases [41], xanthine oxidoreductase [42], thioredoxin reductase $[43,44]$, topoisomerase IIa [45-47] or succinate and NADH dehydrogenases [48] and, mainly, the ribonucleotide reductases (RDRs, [49-51]), where TSC-Fe and TSC-Cu complexes seem to affect the tyrosyl radical in the active site [52] or to sequestrate the iron from the active centre [53]. The presence of redox-active metal 
ions also provokes the interaction with cell thiols and further formation of reactive oxygen species (ROS) triggers oxidative processes in different cell structures and organelles [54-56]. Thus, the reduced form of glutathione (GSH) reacts with TSC-Cu ${ }^{\text {II }}$ and TSC-Fe ${ }^{\mathrm{III}}$ entities to give oxidized GSSG species and $\mathrm{Cu}^{\mathrm{I}}$ or $\mathrm{Fe}^{\mathrm{II}}$ ions [57], whose re-oxidation processes yield ROS $[58,59]$. After reduction, the $\mathrm{Fe}^{\mathrm{II}}$ metal ions use to retain their coordination to tridentate NNS and ONS TSC ligands (where the first N and O represent donor atoms arising from pyridine and phenol substituents, respectively), giving rise to $\mathrm{Fe}(\mathrm{TSC})_{2}$ biscomplexes $[57,60,61]$. The $\mathrm{Cu}^{\mathrm{I}}$ ions, however, could exhibit different behaviors. The evolution of the metal ion has been described for bidentate TSCs, as HTTSC (thiophene-2-carbaldehyde thiosemicarbazone [62], see Scheme 1). In the case of tridentate TSCs, as HPTSC (pyridine-2-carbaldehyde thiosemicarbazone, Scheme 1) early EPR and UV-vis studies supported the survival of the HPTSC-Cu ${ }^{\mathrm{I}}$ complex [63], while others suggested the formation of HPTSC-Cu ${ }^{\text {II }}-$ SG species in red cells [64], but the uncertainty remains at present. Regarding the use of different reductants, no reaction has been observed for the HPTSC-Cu ${ }^{\text {II }}$ system by using ascorbic acid, while GSH, dithiothreitol, 3-mercaptopropionic and 2-mercaptoethanol were found to be active $[57,65]$. These facts reflect the important role that coordination to Fe and $\mathrm{Cu}$ plays in the biological activity of TSCs. In this sense, it has been demonstrated that lysosomal apoptotic pathway in cancer cells is activated through copper sequestration by thiosemicarbazones [66-69], while the copper transporter 1 protein (CTR1) increases the thiosemicarbazone uptake by cisplatin-resistant cell lines [70]. In a recently published study on the cytotoxicity of thiosemicarbazones, the addition of $\mathrm{Cu}^{\mathrm{II}}$ ions has been found to inactivate 3-aminopyridine-2-carbaldehyde thiosemicarbazone (Triapine $^{\circledR}$ ) while increases the activity of di-2-pyridylketone 4,4- 
dimethyl-3-thiosemicarbazone (Dp44mt) [71,72] and bis-thiosemicarbazonato ligands [73].

Promising results in cells and animals [74-79] prompted the researches to test these substances as antitumor therapeutics in humans. In particular, 5-hydroxypyridine2-carbaldehyde thiosemicarbazone (5OHPTSC) was evaluated in phase I clinical trials [80], while Triapine $^{\circledR}$ has been tested in phase I and phase II ones [81-89]. Unfortunately, up to date the results have been disappointed. The decrease in the effectiveness in comparison with that observed in animals seems to be related with different drawbacks, as side effects, toxicity and lowest clearance times [80]. Coordination to metal ions could provide better results [90].

Colorectal cancer (CRC) is the third most common cancer worldwide [91,92]. Among the most frequent mutations in CRC are gain-of-function missense mutations in KRAS and BRAF [93,94,95]. Several studies have indicated that these mutations play distinct roles in development and therapy resistance of CRC [96]. Recently, the effects of the interaction of ribonucleotide reductases with thioredoxin [97] and the influence of the negatively regulated miRNA-mRNA pairs [98] and ribosome-inactivating stress [99] in CRC have been discussed. Taking into account that, as previously mentioned, both ribonucleotide reductases and RNA are targets of TSCs, and previous studies show the attack of CRC cells by TSCs $[100,101]$, it could be interesting to apply these compounds to resistant CRC cells.

In order to shed light on the reaction of thiosemicarbazonecopper(II) species with GSH, we have revisited this reaction using for the first time ESI mass spectrometry techniques over solutions of the $\left[\mathrm{Cu}(\mathrm{PTSC})\left(\mathrm{ONO}_{2}\right)\right]_{\mathrm{n}}(\mathbf{1})$ and $\left[\left\{\mathrm{Cu}\left(\mathrm{PTSC}^{*}\right)\left(\mathrm{ONO}_{2}\right)\right\}_{2}\right]$ (2) compounds, where HPTSC* = pyridine-2-carbaldehyde 4N- 
methylthiosemicarbazone. 2 is fully characterized in the Literature [102], while the structure of the former and some of its magnetic and spectroscopic properties remained undescribed despite being used several times as starting material [103-105]. The reactivity of 1, 2 and the free thiosemicarbazone ligands with cytochrome c and myoglobin is also discussed. Finally, biological activity against CRC cells is analyzed and the interplay with the GSH reactivity is reported. In this sense, the experimental models chosen for the study of the efficacy of the TSCs in the treatment of colon cancer have been the SW480 and HT-29 cell lines that show different mutational status: HT-29 cells have B-RAF mutation while K-RAS mutation occurs in SW480 cells [106].

\section{2.- Experimental Section}

\subsection{Preparation of the compounds.}

HPTSC and HPTSC* were synthesized by condensation of pyridine-2carbaldehyde with the corresponding thiosemicarbazide in ethanol following published methods [107-109], in the case of HPTSC* after previous preparation of $4 \mathrm{~N}$ methylthiosemicarbazide from methylisothiocyanate and hydrazine [110]. Copper(II) nitrate trihydrate (Fluka, Sigma-Aldrich), pyridine-2-carbaldehyde (Fluka), thiosemicarbazide (Fluka), methylisothicyanate (Aldrich, Acros) and hydrazinium hydroxide (Merck) were used as received. The synthesis of compound 2 has been reported elsewhere [102].

The synthesis of compound $\mathbf{1}$ has been described in the Literature [103]. We have carried out slight modifications of the method, which are relevant for some of the physical and chemical properties as it will be discussed later. $\mathrm{Cu}\left(\mathrm{NO}_{3}\right)_{2} \cdot 3 \mathrm{H}_{2} \mathrm{O}(1.00$ mmol, $0.242 \mathrm{~g})$ was dissolved in water $(15 \mathrm{~mL})$ and solid HPTSC (1.01 mmol, $0.183 \mathrm{~g})$ was added. After $1 \mathrm{~h}$, a dark green solution ( $\mathrm{pH}$ 1.40) is obtained with small amounts of 
olive-green precipitate suspended in it. Then, some drops of $\mathrm{NaOH} 1 \mathrm{M}$ solution are slowly added to $\mathrm{pH}$ 3.5. The suspension is kept with stirring for $1 \mathrm{~h}$. Finally, an olivegreen solid is filtered off and washed with acetone $(20 \mathrm{~mL})$ and ethyl ether $(20 \mathrm{~mL})$. The average yield is $56 \%, 0.172$ g. Anal. found: C, 27.57; H, 2.26; N, 22.89; S, 10.27. Calc. for $\mathrm{C}_{7} \mathrm{H}_{7} \mathrm{CuN}_{5} \mathrm{O}_{3} \mathrm{~S}$ (304.77 g/mol): C, 27.59; $\mathrm{H}, 2.32 ; \mathrm{N}, 22.98 ; \mathrm{S}, 10.52$. $\rho_{\text {experimental }}=1.903(5)\left(\mathrm{Mg} / \mathrm{m}^{3}\right)$. IR bands $\left(\mathrm{cm}^{-1}\right.$, ATR $): 3297(\mathrm{~m}), 3153(\mathrm{~s}), 1643(\mathrm{~s})$, 1610(s), 1592(m,sh), 1566(w), 1487(w), 1459 (s,sh), 1445(s), 1437(s), 1386(s)$\mathrm{v}_{3}\left(\mathrm{NO}_{3}{ }^{-}\right), 1371$ (s,sh), 1322(vs), 1302(vs,sh), 1271(s), 1222(s), 1150(vs), 1111(m), 1050(w), 1020(w)- $\mathrm{v}_{1}\left(\mathrm{NO}_{3}{ }^{-}\right), 969(\mathrm{vw}), 919(\mathrm{~m}), 884(\mathrm{~s}), 827(\mathrm{w})-\mathrm{v}_{2}\left(\mathrm{NO}_{3}{ }^{-}\right), 822(\mathrm{vw}, \mathrm{sh})-$ $\mathrm{v}_{2}\left(\mathrm{NO}_{3}{ }^{-}\right), 773(\mathrm{~m}, \mathrm{sh}), 768(\mathrm{~m}), 749(\mathrm{~m}), 742(\mathrm{~m}, \mathrm{sh}), 709(\mathrm{w}), 651(\mathrm{w}), 626(\mathrm{~m})$, 556(m,b), 512(m), 465(m), 438(vw), 414(m). FAB ${ }^{+}$mass spectrometry (m/z): $241.89[\mathrm{CuL}]^{+} . \mathrm{Q}^{-}$ band EPR signal at RT: $g=2.076$. Small single crystals suitable for X-ray structural determination were obtained from slow evaporation of the mother liquours for two months.

Solids recovered after reaction of thiols, as glutathione (GSH) and 2mercaptoethanol (2-MER), were also studied. To achieve this, it was selected $\mathrm{Cu}\left(\mathrm{ClO}_{4}\right)_{2} \cdot 6 \mathrm{H}_{2} \mathrm{O}$ as copper(II) salt because its reaction with HPTSC and HPTSC* yields solids more soluble in water than $\mathbf{1}$ and 2 , and allows to obtain relatively high concentrations of $[\mathrm{Cu}(\mathrm{TSC})]^{+}$species in aqueous solution. In a typical experiment, $\mathrm{Cu}\left(\mathrm{ClO}_{4}\right)_{2} \cdot 6 \mathrm{H}_{2} \mathrm{O}(0.30 \mathrm{mmol}, 0.111 \mathrm{~g})$ was dissolved in water $(20 \mathrm{~mL})$ and solid HPTSC / HPTSC* (0.30 mmol, 0.054 and 0.058 g, respectively) was added. After 30 min, the solution is filtered off. Then, a solution of the thiol ( $3 \mathrm{mmol})$ was poured into and the $\mathrm{pH}$ is adjusted to 7.4 by addition of $\mathrm{NaOH}$. The reaction was kept with stirring for $2 \mathrm{~h}$, and yellow precipitates were filtered off, which were characterized as HPTSC and HPTSC*. When the same reactions were carried out at $\mathrm{pH} 2$, brown unidentified 
solids were obtained, while the evaporation of the mother liquors allowed to isolate crystals corresponding to the $\left(\mathrm{H}_{2} \mathrm{PTSC}\right)\left(\mathrm{ClO}_{4}\right)\left(\mathrm{H}_{2} \mathrm{O}\right)_{0.5}$ and $\left(\mathrm{H}_{2} \mathrm{PTSC}^{*}\right)\left(\mathrm{ClO}_{4}\right)$ compounds. Anal. Found: C, 28.63; H, 3.14; N, 19.47. Calc. for $\left(\mathrm{H}_{2} \mathrm{PTSC}\right)\left(\mathrm{ClO}_{4}\right)\left(\mathrm{H}_{2} \mathrm{O}\right)_{0.5} \mathrm{C}_{7} \mathrm{H}_{10} \mathrm{ClN}_{4} \mathrm{O}_{4.5} \mathrm{~S}$ (289.70 g/mol): C, 29.02; H, 3.48; N, 19.34. IR bands (cm ${ }^{-1}$, FT-IR): 3392(m), 3250(m), 3169(m), 3096(w), 1617(vs), 1586(m), 1513(vs), 1455(w), 1355(m), 1275(m), 1246(m), 1122(vs), 1084(vs), 1057(w), 919(m), 877(m), 855(m), 828(m), 770(f), 726(m), 622(m), 592(w), 549(w), 512(w), 449(w), 429(w).

\subsection{Physical Measurements.}

Measurements of $\mathrm{pH}$ were made using a CRISON micropH 2002 instrument. Microanalyses were performed with a LECO CHNS-932 analyser. The experimental density was determined on pellets of a powdered sample of 1 by the flotation method in a bromoform / chloroform mixture. $\mathrm{FAB}^{+}$and ESI mass spectrometry data were obtained on a Micromass AutoSpec and a Bruker Esquire 3000 Plus LC-MAS, respectively. Thermogravimetric measurements were performed in a Netzsch STA 449C and in a TA SDT 2960 instruments. Crucibles containing $20 \mathrm{mg}$ of sample were heated at $10{ }^{\circ} \mathrm{C} \min ^{-1}$ under dry air atmosphere. FT-IR ATR measurements have been carried out in a JASCO FT-IR 4200 spectrometer equipped with an ATR PRO410-S accessory. The intensities of reported IR bands are defined as vs = very strong, $\mathrm{s}=$ strong, $\mathrm{m}=$ medium and $\mathrm{w}=$ weak, while $\mathrm{b}$ means a broad band and sh is a shoulder. X-band EPR spectra were recorded on a Bruker EMX spectrometer, equipped with a standard Oxford continuous-flow cryostat. Q-band measurements were carried out by a Bruker ESP300 spectrometer equipped with a Bruker BNM 200 gaussmeter and a Hewlett-Packard 5352B microwave frequency counter to fit the magnetic field and the frequency inside the cavity. The simulation of the EPR spectra was performed using the 
SimFonia program [111]. Magnetic measurements of powdered samples were carried out in the temperature range 5-300 K using a Quantum Design MPMS-7 SQUID magnetometer and operating with a magnetic field of $0.1 \mathrm{~T}$. Diamagnetic corrections were estimated from Pascal tables.

\subsection{Crystal structure determination.}

Crystal data collection for compound 1 was carried out on a STOE StadiVari Pilatus-100K single-crystal diffractometer using monochromated MoK $\alpha$ radiation $(\lambda=$ $0.71069 \AA$ ). Absorption correction was made by Gaussian integration. Direct methods (SIR97) [112] were employed to solve the structure and then refined using the SHELXL-2013 computer program [113] within WINGX [114]. The non-H atoms were anisotropically refined, using weighted full-matrix least-squares on $F^{2}$. The $\mathrm{H}$ atoms (excluding those of the water molecules) were included in calculated positions and refined as riding atoms. Selected crystallographic and refinement details are shown in Table 1. CCDC 1424631 contains the supplementary crystallographic data. These data can be obtained free of charge via http://www.ccdc.cam.ac.uk/conts/retrieving.html, or from the Cambridge Crystallographic Data Centre, 12 Union Road, Cambridge CB2 1EZ, UK; fax: (+44) 1223-336-033; or e-mail: deposit@ccdc.cam.ac.uk.

\subsection{Mass spectrometry measurements.}

Compound 1 was dissolved in DMSO for ESI and $\mathrm{FAB}^{+}$measurements (the latter, in NBA matrix). In the case of the ESI analysis of the reaction with GSH, various experiments were performed in air by using different $\mathrm{Cu}^{\mathrm{II}}$ compounds $(\mathbf{1}, \mathbf{2}$, $\mathrm{Cu}\left(\mathrm{NO}_{3}\right)_{2} \cdot 3 \mathrm{H}_{2} \mathrm{O}$ and $\left.\mathrm{Cu}\left(\mathrm{ClO}_{4}\right)_{2} \cdot 6 \mathrm{H}_{2} \mathrm{O}\right)$, together with reduced $\mathrm{GSH}$ and oxidized GSSG in (1:2) and (1:10) metal-thiol ratios. In a typical assay, $10^{-3} \mathrm{M}$ solutions of the metal ion in an aqueous solution of methanol (10\% methanol/water, and $0.1 \%$ formic acid) 
were used, whose $\mathrm{pH}$ was adjusted to 5-7 by addition of drops of a $0.1 \mathrm{M} \mathrm{NaOH}$ solution.

Regarding the experiments on the interaction with cytochrome c and myoglobin, stock aqueous solutions of lyophilized commercial proteins (Sigma-Aldrich) and stock DMSO solutions of the thiosemicarbazone derivatives were used. Protein:compound (1:5) ratio solutions in $\mathrm{NH}_{4} \mathrm{HCO}_{3}$ buffer ( $25 \mathrm{mM}, \mathrm{pH} 7.0$ ) were incubated for $24 \mathrm{~h}$ at 37 ${ }^{\circ} \mathrm{C}$. An ESI-TOF-MS spectrometer with coupled HPLC pump with pH 7.0 mobile phase was used, with $4500 \mathrm{~V}$ and $100{ }^{\circ} \mathrm{C}$ experimental conditions. Solubility problems with compound 1 afforded a protein:compound ratio slightly lower than 1:5.

\subsection{Biological essays.}

\subsubsection{Cell culture and treatment.}

The human colon adenocarcinoma cell lines HT-29 and SW480 (European Collection of Authenticated Cell Cultures, Salisbury, UK) were grown in DMEM containing 25 mM D-glucose supplemented with 10\% fetal bovine serum (FBS), 1\% penicillin/streptomycin (P/S), and $1 \%$ L-glutamine solutions at $37{ }^{\circ} \mathrm{C}$ in a humidified incubator with $5 \% \mathrm{CO}_{2}$. Treatments were prepared in DMEM supplemented with 1\% FBS, 1\% P/S, 1\% L-glutamine solution, and 0.1\% DMSO, which was used to dissolve the HPTSC and HPTSC* and their $\mathrm{Cu}^{\mathrm{II}}$ complexes. For all experiments, HT-29 and SW480 cells were seeded at a $210^{6}$ cells $/ \mathrm{cm}^{2}$ density and cultured $24 \mathrm{~h}$ with growing DMEM. The treated-cells were exposed for $24 \mathrm{~h}$ to treatments at concentrations of 5.5 $\mu \mathrm{M}$. After either the $24 \mathrm{~h}$ treatment or the oxidation period, the cells were scraped and centrifuged ( $800 \mathrm{~g}, 5 \mathrm{~min}, 25^{\circ} \mathrm{C}$ ). The cell pellets were re-suspended in $1 \mathrm{~mL}$ of PBS, aliquoted, and frozen at $-80{ }^{\circ} \mathrm{C}$ until their use for the assays. All the experiments were carried out as three independent assays.

\subsubsection{Anti-proliferative activity evaluation (MTT assay).}


The ability of the thiosemicarbazones and their $\mathrm{Cu}^{\mathrm{II}}$ complexes to inhibit cell proliferation was evaluated by the MTT colorimetric method, which was used to estimate cell viability [115]. Briefly, cells were incubated in 96-well multiplates (1.0x $10^{4}$ cells/well filled with $200 \mu \mathrm{L}$ of medium) for $24 \mathrm{~h}$ under basal conditions and then exposed for other $24 \mathrm{~h}$ to different concentrations of the treatments $(2,4,6,8,10$, 20, 25, $50 \mu \mathrm{g}$ per $\mathrm{mL}$ of medium of each treatment HPTSC, HPTSC*, 1 and 2) or just DMEM for the not treated cells (NT). Then, MTT reagent dissolved in PBS was added to the wells at a final concentration of $0.5 \mathrm{mg} / \mathrm{mL}$ of $\mathrm{DMEM}$ and the plate was maintained in the incubator for $2 \mathrm{~h}$. After incubation for $2 \mathrm{~h}$ with the MTT solution, the medium was removed and $200 \mu \mathrm{L}$ DMSO were added to each well. The absorbance at $570 \mathrm{~nm}$ was measured in a microplate spectrophotometer (MultiSkan, Thermofisher). The experiments were repeated three times in four parallel wells. The $\%$ of viable cells was calculated with respect to the NT cells and the concentration of each treatment that inhibited $50 \%$ of cell viability $\left(\mathrm{IC}_{50}\right.$ ) was determined, expressing the $\mathrm{IC}_{50}$ values for each fraction in $\mu \mathrm{M}$.

\subsubsection{Glutathione reduced/oxidized (GSH/GSSG) ratio analysis.}

Aliquots of the HT29 and SW480 suspensions collected after the treatment period were immediately acidified with $\mathrm{HClO}_{4}$ (2\% final concentration), centrifuged (8000 rpm, 5 min, $4{ }^{\circ} \mathrm{C}$ ), and the supernatants were frozen at $-80^{\circ} \mathrm{C}$ until their use as samples. GSH and GSSG levels in these samples were determined using the reaction between the sulfhydryl group of the GSH and DTNB (5,5'-dithio-bis-2-nitrobenzoic acid, Ellman's reagent). The GSTNB (mixture between GSH and TNB) formed is reduced by glutathione reductase to recycle GSH and produce more TNB. The rate of TNB produced is directly proportional to the recycling reaction, and is directly proportional to the concentration of GSH in the sample. The measurement of TNB absorbance at 410 
$\mathrm{nm}$ provides an accurate estimate of the GSH content in the sample. Briefly, $75 \mu \mathrm{L}$ of the cellular suspension was neutralized with triethanolamine $4 \mathrm{M}$ and derivatized with vinylpyridine for $1 \mathrm{~h}$. Then $10 \mu \mathrm{L}$ of the mixture were incubated with $190 \mu \mathrm{L}$ of the master mix, which contained NAPDH, DTNB and glutathione reductase. The kinetic of the enzyme was followed up during 20 min with a plate spectrophotometer (MultiSkan, Thermoficher).

\subsubsection{Carbonyl group.}

Protein oxidation was measured by an estimation of carbonyl groups released during the incubation time using the method of Levine et al [116]. Following, $150 \mu \mathrm{L}$ of the cellular suspension was placed in a $1.5 \mathrm{~mL}$ Eppendorf, and $500 \mu \mathrm{L}$ of $10 \mathrm{mM}$ 2,4dinitrophenylhydrazine (DNFH) / $2 \mathrm{M} \mathrm{HCl}$, and $500 \mu \mathrm{L}$ of $\mathrm{HCl} 2 \mathrm{M}$ were added to the control samples. This mixture was incubated for $1 \mathrm{~h}$ at room temperature. Protein precipitation was performed using $500 \mu \mathrm{L}$ of $20 \%$ (w/v) of trichloroacetic acid, washing twice with ethanol/ethyl acetate $(1: 1 \mathrm{v} / \mathrm{v})$, and samples were centrifuged at $6000 \mathrm{~g}$ for 3 min. Finally, $1 \mathrm{~mL}$ of $6 \mathrm{M}$ guanidine, $\mathrm{pH} 2.3$, was added and the samples were incubated in a $37{ }^{\circ} \mathrm{C}$ water bath for $30 \mathrm{~min}$. Protein concentration was calculated by absorption spectrophotometry at $373 \mathrm{~nm}$, using a molar absorption coefficient of 22000 $\mathrm{M}^{-1} \mathrm{~cm}^{-1}$. Results are expressed as $\mathrm{nmol} / \mathrm{mg}$ protein.

\subsubsection{Superoxide dismutase activity (SOD).}

SOD activity was assayed according to the method of McCord and Fridowich [117] based on its ability to inhibit the oxygen-dependent reduction of cytochrome c by xanthine oxidase. The activity of the SOD was measured by monitoring at $550 \mathrm{~nm}$ the rate of reduction of cytochrome $c\left(0.3 \mathrm{mmolL}^{-1}\right)$ by superoxide radicals produced by the xanthine $\left(0.3 \mathrm{mmolL}^{-1}\right) /$ xanthine oxidase in a $\mathrm{pH} 7.8$ buffer containing $50 \mathrm{mmolL}^{-1}$ 
potassium phosphate and $0.1 \mathrm{mmolL}^{-1}$ EDTA. One unit of SOD activity was defined as the amount of SOD that inhibited cytochrome $c$ reduction by $50 \%$.

\section{3.- Results and discussion}

\section{1.- Synthesis, structure, spectroscopic and magnetic characterization of $\mathbf{1}$.}

The synthesis of compound $\mathbf{1}$ is apparently easily to achieve starting from aqueous solutions of $\mathrm{Cu}\left(\mathrm{NO}_{3}\right)_{2}$ and solid HPTSC ligand. However, subtle modifications of the synthetic method, i.e. longer reaction times and slightly higher $\mathrm{pH}$ values, lead to samples of 1 with an increasing amount of impurities, mainly detected as rhombic EPR chromophores arising from the isotropic signal. A study to unveil the nature of the impurities is currently in process. The attainment of good single crystals is a quite difficult task too and, after using many crystallization strategies as diffusion devices, addition of supplementary nitrate sources $\left(\mathrm{NaNO}_{3}\right)$, vapour diffusion (acetone into aqueous solutions of $\mathbf{1}$ ), layering techniques... we succeed with one of the multiple slow evaporation experiments we tried. In this sense, the gradual acidification of the solution after addition of the thiosemicarbazone ligand must be taken into account once the precipitate of $\mathbf{1}$ has been removed from the suspension and, if no addition of base is carried out, mother liquours acquire $\mathrm{pH} 0.8$ and the $\left[\mathrm{Cu}\left(\mathrm{ONO}_{2}\right)(\mathrm{HPTSC})\left(\mathrm{OH}_{2}\right)\right]\left(\mathrm{NO}_{3}\right)$ derivative with the neutral ligand crystallizes [118]. On the other hand, solutions with $\mathrm{pH}$ values above 7 give rise to desulfurization processes and yield mixtures of compounds $[119,120]$.

The crystal lattice of $\mathbf{1}$ contains penta- and hexacoordinate $\mathrm{Cu}^{\mathrm{II}}$ ions that alternate to form chains in the [001] direction where the hydrazinic moiety (N2-N3 fragment) of the tiosemicarbazone ligand acts as a bridge. These chains are connected through bidentate ( $\mu$ - $\mathrm{O} 21: \kappa \mathrm{O} 31)$ nitrato ligands along the $\mathrm{X}$ axis to give a 2D structure (see Figure 1). The deprotonated PTSC $^{-}$ligand behaves as tetradentate and links a metal 
center by the $\mathrm{N}_{\text {pyridine, }} \mathrm{N}_{\text {azomethine }}$ and $\mathrm{S}_{\text {thioamide }}$ atoms, while the hydrazinc $\mathrm{N}$ one (N31 or N32, respectively) acts as a connector to the contiguous $\mathrm{Cu}^{\mathrm{II}}$ ion. Thus, two kinds of polyhedra are defined: tetragonally distorted octahedral and square-pyramidal $(\mathrm{Cu} 2, \tau=$ 0.09) [121] ones (see Figures 2 and 3, Table 2). The average planes of adjacent thiosemicarbazone ligands in the chain form angles of $67.2(1)^{\circ}$. In spite of the planarity of the $[\mathrm{Cu}(\mathrm{PTSC})]^{+}$fragments, they arrange far enough and no intense $\pi-\pi$ stacking interactions seem to be established. On the other hand, strong hydrogen bonds are present in the crystal building, being remarkable the intrachain N42 $\cdots$ O31 contact at 2.94(2) $\AA$ (see Supporting Information). Disorder is observed in the nitrato ligands of the square-pyramidal monomers. The closest $\mathrm{Cu} 1{ }^{\cdots} \mathrm{Cu} 2^{\mathrm{i}}$ distances are $4.832(2) \AA$ (i $=$ $\mathrm{x}, \mathrm{y}, 1+\mathrm{z}$ ), while $\mathrm{Cu} 1$ and $\mathrm{Cu} 1^{\mathrm{ii}}$ are $7.472(2) \AA$ (ii $\left.=1+\mathrm{x}, \mathrm{y}, \mathrm{z}\right)$ away linked by nitrato ligands. The whole structure resembles that of the DMSO derivative [122] of 1 . However, the presence of DMSO ligands in the latter originates an strict 1D structure of tetragonally distorted $\left[\mathrm{Cu}(\mathrm{PTSC})(\mathrm{DMSO})\left(\mathrm{ONO}_{2}\right)\right]$ monomers bridged through the hydrazinic fragment of the thiosemicarbazone ligand. The role of the hydrazinic N3 as a donor atom is not usual in the thiosemicarbazone chemistry, however some examples are reported in the Literature [123-125].

The intensities of the IR bands around $1645-1610 \mathrm{~cm}^{-1}$, attributed to $v(\mathrm{C}=\mathrm{N})_{\text {azomethinic }}, \quad v(\mathrm{C}=\mathrm{N})_{\text {pyridinic }}$ and $\delta\left(\mathrm{NH}_{2}\right)$ modes and lower than those absorptions observed in the $1460-1430 \mathrm{~cm}^{-1}$ range assigned to thioamide II vibrations, clearly indicate the anionic character of the thiosemicarbazone ligand [126]. X-band EPR spectra of different polycrystalline samples of $\mathbf{1}$ at room temperature show a weak and very broad $(\approx 480 \mathrm{G})$ isotropic signal, with an approximate $g$-value of $2.06(g=2.076$ when measured in Q-band, see Figure 4), which remains unchanged on decreasing temperatures. Taking into account the high asymmetry in these systems, the existence 
of thermally invariable isotropic signals suggests the presence of a strong exchange coupling between adjacent chromophores. Figure 5 exhibits the thermal evolution of $\chi_{\mathrm{m}}$ and $\chi_{\mathrm{m}} T$. A maximum in the $\chi_{\mathrm{m}} v s T$ plot is observed around $160-170 \mathrm{~K}$, characteristic of antiferromagnetic interactions. From a quantitative point of view, it has already been described in the Literature the unusually low value for the magnetic moment of this compound at room temperature [103]. However, as far we are aware, its variable temperature magnetic measurements have not been studied. Preliminary experimental results are described using a Heissenberg model for $S=1 / 2$ chains with antiferromagnetic interactions (Equations 1 and 2, [127]). The deduced $J / k$ parameter is $-126 \mathrm{~K}\left(-87.5 \mathrm{~cm}^{-1}\right)$. The strong antiferromagnetic coupling supports an exchange propagation direction in the same plane of the magnetic $d_{x} 2-y^{2}$ orbitals.

$$
\begin{aligned}
& \mathrm{H}=-2 J \sum_{\mathrm{i}=1}^{\mathrm{n}-1} \mathrm{~S}_{\mathrm{Ai}} \cdot \mathrm{S}_{\text {AiH }} \\
& \chi_{m}=\frac{N g^{2} \beta^{2}}{k T} \frac{0.25+0.14995 \mathrm{x}+0.30094 \mathrm{x}^{2}}{1+1.9862 \mathrm{x}+0.68854 \mathrm{x}^{2}+6.0626 \mathrm{x}^{3}}
\end{aligned}
$$

where $\mathrm{x}=\frac{|2 \mathrm{~J}|}{k T}$.

\section{2.- Reactivity with glutathione, cytochrome c and myoglobin.}

Concerning the reaction with thiols (RSH) as reduced glutathione (GSH), 2mecaptoethanol (2-MER) and oxidized glutathione (GSSG), all the attempts carried out to synthesize ternary $\mathrm{Cu}^{\mathrm{II}}$ - HPTSC / HPTSC* - RSH / RSSR compounds at different $\mathrm{pH}$ values have been unsuccessful. In fact, the only well characterized solid compounds collected from the addition of GSH and 2-MER over $2.510^{-2} \mathrm{M}$ solutions of previously 
mixed $\mathrm{Cu}\left(\mathrm{ClO}_{4}\right)_{2} \cdot 6 \mathrm{H}_{2} \mathrm{O}$ and $\mathrm{HL}$ at $\mathrm{pH} 7.4$ are the free HPTSC and HPTSC* ligands. On the other hand, the evaporation of aqueous solutions at $\mathrm{pH} 2.0$ have yielded the $\left(\mathrm{H}_{2} \mathrm{PTSC}\right)\left(\mathrm{ClO}_{4}\right) \cdot \mathrm{H}_{2} \mathrm{O}$ and $\left(\mathrm{H}_{2} \mathrm{PTSC}^{*}\right)\left(\mathrm{ClO}_{4}\right)$ derivatives containing pyridinium-2carbaldehyde thiosemicarbazone cations, whose structure with chloride anions has been published [128].

ESI mass spectrometry measurements on the reaction of $\mathbf{1}$ and $\mathbf{2}$ with GSH have been performed for 1:1 and 1:10 (complex:GSH) ratios at different times. The same procedure has been used in the reaction with oxidized GSSG. Nitrate and perchlorate copper(II) salts have been also evaluated in the same way for comparative purposes. In good accordance with the solids obtained in the synthetic trials, the spectra do not evidence the presence of ternary thiosemicarbazonecopper(II)-glutathione TSC-CuGSH/GSSG species in the experimental conditions (see Supporting Information). A proposed chain of reactions is given in Equations 3-8, where TSCs are represented by $\mathrm{HL}$ and thiols as RSH. Both, $\mathrm{Cu}^{\mathrm{I}}$ and $\mathrm{Cu}^{\mathrm{II}}$ ions, could be sequestrated by GSSG or GSH, be linked to the TSC or even be solvated in the water-methanol-formic acid mixture. In these conditions, the competition between the chelating abilities of TSC and thiol/disulfide (GSH/GSSG) would afford the release of the soft acid $\mathrm{Cu}^{\mathrm{I}}$ ions from the TSC and the formation of GSH/GSSG-Cu${ }^{I}$ species, as the ESI spectra suggest. The detachment of $\mathrm{Cu}^{\mathrm{I}}$ ions from the thiosemicarbazone (Step 1) agrees well with the loss in stability foreseen by crystallographic studies, which evidence drastic structural changes between HPTSC-Cu ${ }^{\mathrm{II}}$ complexes ( $\mathrm{Cu}^{\mathrm{II}}$ ions strongly linked to tridentate NNS TSCs) and HPTSC-Cu${ }^{\mathrm{I}}$ systems, where $\mathrm{Cu}^{\mathrm{I}}$ ions are only bonded to the thioamide $\mathrm{S}$ atom [129]. Re-oxidation processes in the metal ions are concomitant with the coordination of the recovered $\mathrm{Cu}^{\mathrm{II}}$ ions to the thiosemicarbazone (Step 2), which is visualized from the increase with time in the intensity of the peaks at $\mathrm{m} / \mathrm{z} 241.9$ and 255.9, 
corresponding to the $[\mathrm{Cu}(\mathrm{TSC})]^{+}$species. The reactive oxygen species (ROS) generated could induce the oxidative rupture of different cell structures (Step 3). These results are not in good agreement with previously reported studies in solution, which suggested the formation of thiosemicarbazonecopper(II)-glutathione complexes [63,64]. The divergences could be due to (i) drastic influences of the thiol and complex concentrations, higher in the work here reported, (ii) the medium used in our ESI measurements (see experimental details), or perhaps (iii) to misinterpretation of the EPR and UV-visible spectroscopic measurements caused by the complexity of the speciation in these solutions.

1) $2[\mathrm{CuL}]^{+}+2 \mathrm{RSH} \rightarrow 2 \mathrm{Cu}^{+}+2 \mathrm{HL}+\mathrm{RSSR}$

(Equation 3)

2) $\mathrm{Cu}^{2+}+\mathrm{HL} \rightarrow[\mathrm{CuL}]^{+}+\mathrm{H}^{+}$

3) $\mathrm{Cu}^{+}+\mathrm{O}_{2} \rightarrow \mathrm{Cu}^{2+}+\mathrm{O}_{2}^{\cdot-}$

$$
2 \mathrm{O}_{2}^{--}+2 \mathrm{H}^{+} \rightarrow \mathrm{O}_{2}+\mathrm{H}_{2} \mathrm{O}_{2}
$$

$$
\mathrm{Cu}^{+}+\mathrm{H}_{2} \mathrm{O}_{2} \rightarrow \mathrm{Cu} \mathrm{IOOH}+\mathrm{H}^{+}
$$

$$
\mathrm{Cu}^{+}+\mathrm{H}_{2} \mathrm{O}_{2} \rightarrow \mathrm{Cu}^{2+}+\mathrm{OH}^{-}+\mathrm{OH}^{\cdot}
$$

ESI experiments also suggest that free ligands do not show interaction with the proteins assayed, cytochrome c and myoglobin (see Supporting Information), while the interactions are low in the case of $\mathbf{1}$ and 2 . Tests with cytochrome c point to a release of the copper from TSC, in good agreement with the existence of previous reduction processes that provoke binding of presumed $\mathrm{Cu}^{\mathrm{I}}$ ions to cysteine-rich regions in the protein. This behavior is not clear in the case of myoglobin, devoid of cysteine amino acids.

\subsection{Biological activity.}

The anticancer and antioxidant activities of thiosemicarbazones are clearly affected by their structural formulae and interaction with metals [130,131,132]. 
Compounds prepared in this work (HPTSC; 1; HPTSC* and 2) have been tested for antiproliferative activity in the cancer cell lines SW480 and HT-29 that have different mutations.

The antiproliferative activity of the ligands HPTSC and HPTSC* and their $\mathrm{Cu}^{\mathrm{II}}$ complexes has been evaluated after $24 \mathrm{~h}$ of drug treatment, using MTT assay and the results are summarized in Table 3 in terms of IC50 values. The HPTSC and HPTSC* possess low cytotoxicity with IC50 $>20 \mu \mathrm{M}$. The HPTSC and HPTSC* show a cell line-dependent effect, with more cytotoxicity for SW480 than HT-29 line cell. The cytotoxicity of the metal free thiosemicarbazones up to micromolar concentrations are known to be related, at least in part, to their ribonucleotide reductase inhibitory potential $[133,134]$ and a major cytotoxicity in SW480 cells has also been reported [90]. An important structure-activity relationship derived from this study is that the coordination of $\mathrm{Cu}^{\mathrm{II}}$ ions to thiosemicarbazones increases the antiproliferative activity against both colon cancer cells with IC50 $<6 \mu \mathrm{M}$. Although the values of IC50 of compound $\mathbf{2}$ are lower than $\mathbf{1}$, the divergence is not significant and no differences are observed in function of the cell line. The same trend was previously observed on V79 cellular line, where the compound $\mathbf{1}$ showed higher value of cytotoxicity than compound 2 [37].

Oxidative stress has been recognized as a contributing factor in the toxicity of a large number of thiosemicarbazones. ROS have long been established to play a critical role in tumorigenesis and are now considered to be integral to the regulation of diverse signaling networks that drive proliferation, tumor cell survival and malignant progression [135]. It is known that cancer cells operate under basal levels of ROS higher than those in normal cells and, therefore, they become vulnerable to chemotherapeutic agents or redox active agents, such as $\mathrm{Cu}^{\mathrm{II}}$ complexes $[136,137]$. In 
this study, the role of oxidative stress was examined by the ability of the HPTSC free and copper-coordinated to change the levels of oxidative stress in the cell.

The participation of compounds $\mathbf{1}$ and $\mathbf{2}$ to generate ROS has been evaluated quantifying the SOD activity (see Figure 6). The SOD catalyzes the dismutation of the superoxide radical, being the first defense to oxidative stress in cells. Incubation the cell with HPTSC and HTPSC* does not increase the SOD activity relative to control cells. In contrast, incubation of cells with 1 and 2 shows a significant $(\mathrm{p}<0.0001)$ increase in the SOD activity. These results indicate that copper complexes can initiate Fenton reactions, intracellularly resulting in ROS accumulation [54,134]. Furthermore, the $\mathrm{Cu}^{\mathrm{I}}$ ions can react with molecular oxygen and be re-oxidised to $\mathrm{Cu}^{\mathrm{II}}$ generating reactive superoxide radicals (see Equation 4) and thereby increasing the SOD activity. These results demonstrate the ability of the copper complexes to catalyze an increase of ROS levels in the cells. The increment of SOD activity is significantly higher in SW480 than in HT-29.

The increase in ROS levels results in a major damage to biomolecules and has been implicated in carcinogenesis [138]. In this sense, we have evaluated the cell damage quantifying the carbonyl groups (Figure 7). The results show an increase in the levels of carbonyl groups in the cells treated with the complexes $\mathbf{1}$ and $\mathbf{2}$. Furthermore, we observed an influence of the cell line, the levels of carbonyl group being significantly higher in the K-Ras mutated SW480 cells than in HT-29, where K-Ras is wild type. The presence of $K$-Ras mutation in colorectal cancer correlates with a poor prognosis and is associated with lack of response to treatment with EGFR- therapies. In this sense, these complexes would be a good alternative for the treatment of colorectal cancer with $K$-Ras mutated. 
Cellular thiols are also susceptible to react with several oxidants and they are critical to maintain the intracellular thiol redox balance [139]. The GSH / GSSG redox couple has been the traditional marker for the characterization of oxidative stress, because of its high concentrations and direct roles as antioxidants and cellular protectors. The GSH levels are modified when cells are treated with HPTSC and HPTSC* resulting in a decreased of GSH / GSSG (Figure 8). This decrease is major in the cells treated with the metal 1 and 2 complexes. The SW480 treated with 2 is the most susceptible to the oxidation of GSH levels, as the lowest GSH / GSSG values indicate.

\section{4.- Conclusions}

The crystal lattice of $\left[\mathrm{Cu}(\mathrm{PTSC})\left(\mathrm{ONO}_{2}\right)\right]_{\mathrm{n}}$ (1) contains sheets where both, the thiosemicarbazone and nitrato ligands, act as connectors between $\mathrm{Cu}^{\mathrm{II}}$ ions. To achieve this, the thiosemicarbazone behaves as tetradentate, chelating a metal ion through the typical NNS donor set, while the hydrazinic N3 atom links a neighbor $\mathrm{Cu}^{\mathrm{II}}$ ion. On the other hand, 1 shows a relatively strong antiferromagnetic behavior. The reaction of 1 and $\left[\left\{\mathrm{Cu}(\mathrm{P} ' \mathrm{TSC})\left(\mathrm{ONO}_{2}\right)\right\}_{2}\right]$ (2) with thiols as 2-mercaptoethanol (2-MER) and glutathione (GSH) have not allowed the synthesis of any ternary thiosemicarbazonecopper-thiol compound nor the detection of such species by ESI experiments. The low reactivity of $\mathbf{1}$ and $\mathbf{2}$ with cytochrome c and myoglobin suggests no appreciable sequestration by these proteins in physiological media. In addition, 1 and 2 show high cytotoxicity towards SW480 and HT-29 cells, which is accompanied by elevated levels of ROS, oxidation of protein and disturb of the GSH redox. These experimental results indicate that these TSC-Cu complexes are good candidates for further developments as potential anticancer drugs. 


\section{Supplementary material}

Crystallographic data for the structure of $\mathbf{1}$ have been deposited with the Cambridge Crystallographic Data Centre, CCDC-1424631. These data can be obtained free of charge via http://www.ccdc.cam.ac.uk/conts/retrieving.html, or from the Cambridge Crystallographic Data Centre, 12 Union Road, Cambridge CB2 1EZ, UK; fax: (+44) 1223-336-033; or e-mail: deposit@ccdc.cam.ac.uk.

\section{Acknowlegments.}

We thank Dr. J.J. Delgado, Dr. Pilar Castroviejo and Marta Mansilla (SCAI, Universidad de Burgos, Spain) for the elemental analysis and mass spectra and SCSIE (Universidad de València) for mass spectrometry measurements. This work was supported by Obra Social “la Caixa” (OSLC-2012-007), Ministerio de Economía y Competitividad and FEDER funds (CTQ2013-48937-C2-1-P, CTQ2015-70371-REDT, MAT2015-66441-P, BIO2015-67358-C2-2-P), Junta de Castilla y León (BU237U13), Gerencia Regional de Salud, Consejería de Sanidad, Junta de Castilla y León (GRS 1023/A/14), the Basque Government (project IT-779-13). The authors from the UAB are members of the "Grup de Recerca de la Generalitat de Catalunya” ref. 2014SGR423. Universidad de Burgos and Caja de Burgos, Spain, are also gratefully acknowledged. R. G.-G. wishes to thank to the Junta de Castilla y León for his Doctoral Fellowship.

\section{References}

[1] A.G. Quiroga, C. Navarro-Ranninger, Coord. Chem. Rev. 248 (2004) 119-133.

[2] H. Beraldo, Quim. Nova 27 (2004) 461-471.

[3] M. Christlieb, J.R. Dilworth, Chem. Eur. J. 12 (2006) 6194-6206. 
[4] T.S. Lobana, R. Sharma, G. Bawa, S. Khanna, Coord. Chem. Rev. 253 (2009) 977-1055.

[5] A.I. Matesanz, P. Souza, Mini Rev. Med. Chem. 9 (2009) 1389-1396.

[6] J. García-Tojal, R. Gil-García, P. Gómez-Saiz, M. Ugalde, Curr. Inorg. Chem. 1 (2011) 189-210, and references therein.

[7] B.M. Paterson, P.S. Donnelly, Chem. Soc. Rev. 40 (2011) 3005-3018.

[8] J. García-Tojal, R. Gil-García, P. Gómez-Saiz, M. Ugalde, Curr. Inorg. Chem. 1 (2011) 189-210, and references therein.

[9] A. Molter, J. Rust, C.W. Lehmann, G. Deepa, P. Chiba, F. Mohr, Dalton Trans. 40 (2011) 9810-9820.

[10] T.S. Lobana, RSC Adv. 5 (2015) 37231-37274.

[11] P.F. Salas, C. Herrmann, C. Orvig, Chem. Rev. 113 (2013) 3450-3492.

[12] M. Cipriani, J. Toloza, L. Bradford, E. Putzu, M. Vieites, E. Curbelo, A.I. Tomaz, B. Garat, J. Guerrero, J.S. Gancheff, J.D. Maya, C. Olea Azar, D. Gambino, L. Otero, Eur. J. Inorg. Chem. (2014) 4677-4689.

[13] P.P. Netalkar, S.P. Netalkar, V.K. Revankar, Polyhedron. 100 (2015) 215-222.

[14] D. Rogolino, A. Bacchi, L. De Luca, G. Rispoli, M. Sechi, A. Stevaert, L. Naesens, M. Carcelli, J. Biol. Inorg. Chem. 20 (2015) 1109-1121.

[15] J.L. Hickey, S. Lim, D.J. Hayne, B.M. Paterson, M. White, V.L. Villemagne, P. Roselt, D. Binns, C. Cullinane, C.M. Jeffery, R.I. Price, K.J. Barnham, P.S. Donnelly, J. Am. Chem. Soc. 135 (2013) 16120-16132.

[16] J.L. Hickey, P.J. Crouch, S. Mey, A. Caragounis, J.M. White, A.R. White, P.S. Donnelly, Dalton Trans. 40 (2011) 1338-1347.

[17] A. Mrozek-Wilczkiewicz, M. Serda, R. Musiol, G. Malecki, A. Szurko, A. Muchowicz, J. Golab, A. Ratuszna, J. Polanski, ACS Med. Chem. Lett. 5 (2014) 336-339.

[18] C. Stefani, P.J. Jansson, E. Gutierrez, P. V. Bernhardt, D.R. Richardson, D.S. Kalinowski, J. Med. Chem. 56 (2013) 357-370.

[19] J. Shao, Z.-Y. Ma, A. Li, Y.-H. Liu, C.-Z. Xie, Z.-Y. Qiang, J.-Y. Xu, J. Inorg. Biochem. 136 (2014) 13-23.

[20] D. Palanimuthu, S.V. Shinde, K. Somasundaram, J. Med. Chem. 56 (2013) 722734.

[21] F. Bisceglie, S. Pinelli, R. Alinovi, P. Tarasconi, A. Buschini, F. Mussi, A. Mutti, G. Pelosi, J. Inorg. Biochem. 116 (2012) 195-203.

[22] M.D. Hall, K.R. Brimacombe, M.S. Varonka, K.M. Pluchino, J.K. Monda, J. Li, M.J. Walsh, M.B. Boxer, T.H. Warren, H.M. Gales, M.M. Gottesman, J. Med. Chem. 54 (2011) 5878-5889.

[23] R. Prabhakaran, P. Kalaivani, R. Huang, P. Poornima, V. Vijaya Padma, F. Dallemer, K. Natarajan, J. Biol. Inorg. Chem. 18 (2013) 233-247.

[24] Z. Kovacevic, S. Chikhani, Mol. Pharmacol. 80 (2011) 598-609.

[25] M.N.M. Milunovic, É.A. Enyedy, N. V. Nagy, T. Kiss, R. Trondl, M. a. Jakupec, B.K. Keppler, R. Krachler, G. Novitchi, V.B. Arion, Inorg. Chem. 51 (2012) 9309-9321.

[26] Z. Kovacevic, S. Chikhani, Mol. Pharmacol. 80 (2011) 598-609.

[27] K.M. Dixon, G.Y.L. Lui, Z. Kovacevic, D. Zhang, M. Yao, Z. Chen, Q. Dong, S.J. Assinder, D.R. Richardson, Br. J. Cancer 108 (2013) 409-419.

[28] J. Qi, S. Liang, Y. Gou, Z. Zhang, Z. Zhou, F. Yang, H. Liang, Eur. J. Med. Chem. 96 (2015) 360-368. 
[29] S. V Menezes, S. Sahni, Z. Kovacevic, D.R. Richardson, J. Biol. Chem. 292 (2017) 12772-12782.

[30] B. Zou, X. Lu, Q. Qin, Y. Bai, Y. Zhang, M. Wang, Y.-C. Liu, Z.-F. Chen, H. Liang, RSC Adv. 7 (2017) 17923-17933.

[31] K. Brodowska, I. Correia, E. Garribba, F. Marques, E. Klewicka, E. LodygaChruscinska, J.C. Pessoa, A. Dzeikala, L. Chruscinski, J. Inorg. Biochem. 165 (2016) 36-48.

[32] M.T. Basha, J. Bordini, D.R. Richardson, M. Martinez, P. V. Bernhardt, J. Inorg. Biochem. 162 (2016) 326-333.

[33] V.F.S. Pape, S. Tóth, A. Füredi, K. Szebényi, A. Lovrics, P. Szabó, M. Wiese, G. Szakács, Eur. J. Med. Chem. 117 (2016) 335-354.

[34] C.R. Myers, Free Radic. Biol. Med. 91 (2016) 81-92.

[35] Y. Wang, Y. Fang, M. Zhao, M. Li, Y. Ji, Q. Han, MedChemComm. 8 (2017) $2125-2132$.

[36] Y. Fu, Y. Liu, J. Wang, C. Li, S. Zhou, Y. Yang, P.Zhou, C. Lu, C. Li, Oncol. Rep. 37 (2017) 1662-1670.

[37] R. Ruiz, B. García, J. Garcia-Tojal, N. Busto, S. Ibeas, J.M. Leal, C. Martins, J. Gaspar, J. Borras, R. Gil-Garcia, M. Gonzalez-Alvarez, J. Biol. Inorg. Chem. 15 (2010) 515-532.

[38] Saswati, A. Chakraborty, S.P. Dash, A.K. Panda, R. Acharyya, A. Biswas, S. Mukhopadhyay, A. Crochet, Y.P. Patil, M. Nethaji, R. Dinda, Dalton Trans. 44 (2015) 6140-6157.

[39] M. Muralisankar, N.S.P. Bhuvanesh, A. Sreekanth, New J. Chem. 40 (2016) 2661-2679.

[40] R. Gil-Garcia, M. Ugalde, N. Busto, H.J. Lozano, J.M. Leal, B. Perez, G. Madariaga, M. Insausti, L. Lezama, R. Sanz, L.M. Gómez-Sainz, B. Garcia, J. Garcia-Tojal, Dalton Trans. 45 (2016) 18704-18718.

[41] W.C. Kaska, C. Carrano, J. Michalowski, J. Jackson, W. Levinson, Bioinorg. Chem. 3 (1978) 245-254.

[42] M. Leigh, D.J. Raines, C.E. Castillo, A.K. Duhme-Klair, ChemMedChem 6 (2011) 1107-1118.

[43] J.A. Lessa, J.C. Guerra, L.F. de Miranda, C.F.D. Romeiro, J.G. Da Silva, I.C. Mendes, N.L. Speziali, E.M. Souza-Fagundes, H. Beraldo, J. Inorg. Biochem. 105 (2011) 1729-1739.

[44] J.M. Myers, Q. Cheng, W.E. Antholine, B. Kalyanaraman, A. Filipovska, E.S.J. Arnér, C.R. Myers, Free Radic. Biol. Med. 60 (2013) 183-194.

[45] F. Bacher, E.A. Enyedy, N.V. Nagy, A. Rockenbauer, G.M. Bognár, R. Trondl, M.S. Novak, E. Klapproth, T. Kiss, V.B. Arion, Inorg. Chem. 52 (2013) 88958908.

[46] F. Bisceglie, S. Pinelli, R. Alinovi, M. Goldoni, A. Mutti, A. Camerini, L. Piola, P. Tarasconi. G. Pelosi, J. Inorg. Biochem. 140 (2014) 111-125.

[47] F. Bisceglie, A. Musiari, S. Pinelli, R. Alinovi, I. Menozzi, E. Polverini, P. Tarasconi, M. Tavone, G. Pelosi, J. Inorg. Biochem. 152 (2015) 10-19.

[48] K.Y. Djoko, B.M. Paterson, P.S. Donnelly, A.G. McEwan, Metallomics 6 (2014) 854-863.

[49] E.C. Moore, M.S. Zedeck, K.C. Agrawal, A.C. Sartorelli, Biochemistry 9 (1970) 4492-4498.

[50] L. Thelander, A. Gräslund, J. Biol. Chem. 258, (1983) 4063-4066. 
[51] Y. Yu, D.S. Kalinowski, Z. Kovacevic, A.R. Siafakas, P.J. Jansson, C. Stefani, D.B. Lovejoy, P.C. Sharpe, P.V. Bernhardt, D.R. Richardson, J. Med. Chem. 52 (2009) 5271-5294.

[52] A. Ozarowski, L. Filipovic, S. Radulovic, E.A. Enyedy, V.B. Arion, Inorg. Chem. 53 (2014) 12595-12609.

[53] A. Popović-Bijelić, C.R. Kowol, M.E.S. Lind, J. Luo, F. Himo, É.A. Enyedy, V.B. Arion, A. Gräslund, J. Inorg. Biochem. 105 (2011) 1422-1431.

[54] F.N. Akladios, S.D. Andrew, C.J. Parkinson, Bioorganic Med. Chem. 23 (2015) 3097-3104.

[55] D.S. Kalinowski, C. Stefani, S. Toyokuni, T. Ganz, G.J. Anderson, N. V Subramaniam, D. Trinder, J.K. Olynyk, A. Chua, P.J. Jansson, S. Sahni, D.J.R. Lane, A.M. Merlot, Z. Kovacevic, M.L.H. Huang, C. S. Lee, D.R. Richardson, Biochim. Biophys. Acta - Mol. Cell Res. 1863 (2016) 727-748.

[56] F.N. Akladios, S.D. Andrew, C.J. Parkinson, J. Biol. Inorg. Chem. 21 (2016) 407-419.

[57] J. García-Tojal, García-Orad, A Díaz, J.L. Serra, M.K. Urtiaga, M.I. Arriortua, T. Rojo, J. Inorg. Biochem. 84 (2001) 271-278.

[58] Y. Yu, D.S. Kalinowski, Z. Kovacevic, A.R. Siafakas, P.J. Jansson, C. Stefani, D.B. Lovejoy, P.C. Sharpe, P.V. Bernhardt, D.R. Richardson, J. Med. Chem. 52 (2009) 5271-5294.

[59] J.M. Myers, W.E. Antholine, J. Zielonka, C.R. Myers, Toxicol. Lett. 201 (2011) 130-136.

[60] M.I. Arriortua, J. Garcia-tojal, J.L. Pizarro, L. Lezama, Inorg. Chim. Acta. 278 (1998) 150-158.

[61] J. García-Tojal, B. Donnadieu, J.P. Costes, J.L. Serra, L. Lezama, T. Rojo, Inorg. Chim. Acta. 333 (2002) 132-137.

[62] J. García-Tojal, A. García-Orad, J.L. Serra, J.L. Pizarro, L. Lezama, M.I. Arriortua, [T. Rojo, J. Inorg. Biochem. 75 (1999) 45-54.

[63] L.A. Saryan, K. Mailer, C. Krishnamurti, W.E. Antholine, D.H. Petering, Biochem. Pharmacol. 30 (1981) 1595-1604.

[64] W.E. Antholine, F. Taketa, J. Inorg. Biochem. 20 (1984) 69-78.

[65] P. Gómez-Saiz, R. Gil-García, M.A. Maestro, J.L. Pizarro, M.I. Arriortua, L. Lezama, T. Rojo, J. Inorg. Biochem. 102 (2008) 1910-1920.

[66] D.B. Lovejoy, P.J. Jansson, U.T. Brunk, J. Wong, P. Ponka, D.R. Richardson, Cancer Res. 71 (2011) 5871-5880.

[67] C. Stefani, Z. Al-Eisawi, P.J. Jansson, D.S. Kalinowski, D.R. Richardson, J. Inorg. Biochem. 152 (2015) 20-37.

[68] D.B. Lovejoy, P.J. Jansson, U.T. Brunk, J. Wong, P. Ponka, D.R. Richardson, Cancer Res. 71 (2011) 5871-5880.

[69] D.B. Lovejoy, P.J. Jansson, U.T. Brunk, J. Wong, P. Ponka, D.R. Richardson, Cancer Res. 71 (2011) 5871-5880.

[70] K.L. Fung, A.K. Tepede, K.M. Pluchino, L.M. Pouliot, J.N. Pixley, M.D. Hall, M.M. Gottesman, Mol. Pharmaceut. 11 (2014) 2692-2702.

[71] A. Gaál, G. Orgován, Z. Polgári, A. Réti, V.C. Mihucz, S. Bösze, N. Szoboszlai, C. J. Streli, Inorg. Biochem. 2014, 130, 52-58.

[72] K. Ishiguro, Z.P. Lin, P.G. Penketh, K. Shyam, R. Zhu, R.P. Baumann, Y.-L. Zhu, A.C. Sartorelli, T.J. Rutherford, E.S. Ratner, Biochem. Pharmacol. 91 (2014) 312-332. 
[73] M.A. Cater, H.B. Pearson, K. Wolyniec,; Klaver, P.; Bilandzic, M.; Paterson, B. M.; Bush, A.I.; Humbert, P.O.; La Fontaine, S.; Donnelly, P.S.; Haupt, Y. ACS Chem. Biol. 8 (2013) 1621-1631.

[74] R.W. Brockman, J.R. Thomson, M.J. Bell, H.E. Skipper, Cancer. Res. 16 (1956) 167-170.

[75] F.A. French, E.J. Blanz, .J. Med. Chem. 9 (1966) 585-589.

[76] F.A. French, E.J. Blanz, Cancer Res. 26 (1966) 1638-1640.

[77] E.J. Blanz, F.A. French, Cancer Res. 28 (1968) 2419-2422.

[78] E.J. Blanz, F.A. French, J.R. DoAmaral, D.A. French J. Med. Chem. 13 (1970) 1125-1130.

[79] W.A. Creasey, K.C. Agrawal, R.L. Capizzi, K.K. Stonson, A.C. Sartorelli, Cancer Res. 32 (1972) 565-572.

[80] R.C. DeConti, B.R. Toftness, K.C. Agrawal, R. Tomchick, J.A.R. Mead, J.R. Bertino, A.C. Sartorelli, W.A. Creasey, Cancer Res. 32 (1972) 1455-1462.

[81] R.A. Finch, M.-C. Liu, A.H. Cory, J.G. Cory, A.C. Sartorelli, Advan. Enzyme Regul. 39 (1999) 3-12.

[82] L. Feun, M. Modiano, K. Lee, J. Mao, A. Marini, N. Savaraj, P. Plezia, B. Almassian, E. Colacino, J. Fischer, S. MacDonald, Cancer Chemother. Pharmacol. 50 (2002) 223-229.

[83] J. Murren, M. Modiano, C. Clairmont, P. Lambert, N. Savaraj, T. Doyle, M. Sznol, Clin. Cancer Res. 9 (2003) 4092-4100.

[84] F.J. Giles, P.M. Fracasso, H.M. Kantarjian, J.E. Cortes, R.A. Brown, S. Verstovsek, Y. Alvarado, D.A. Thomas, S. Faderl, G. Garcia-Manero, L.P. Wright, T. Samson, A. Cahill, P. Lambert, M. Sznol, J.F. DiPersio, V. Gandhi, Leuk. Res. 27 (2003) 1077-1083.

[85] Y. Yen, K. Margolin, J. Doroshow, M. Gishman, B Johnson, C. Clairmont, D. Sullivan, M. Sznol, Cancer Chemother. Pharmacol. 54 (2004) 331-342.

[86] K.W.L. Yee, J. Cortes, A. Ferrajoli, G. Garcia-Manero, S. Verstovsek, W. Wierda, D. Thomas, S. Faderl, I. King, S.M. O’Brien, S. Jeha, M. Andreeff, A. Cahill, M. Sznol, F.J. Giles, Leuk. Res. 30 (2006) 813-822.

[87] I. Gojo, M.L. Tidwell, J. Greer, N. Takebe, K. Seiter, M.F. Pochron, B. Johnson, M. Sznol, J.E. Karp, Leuk. Res. 31 (2007) 1165-1173.

[88] J.J. Knox, S.J. Hotte, C. Kollmannsberger, E. Winquist, B. Fisher, E.A. Eisenhauer, Invest. New Drugs 25 (2007) 471-477.

[89] J.E. Karp, F.J. Giles, I. Gojo, L. Morris, J. Greer, B. Johnson, M. Thein, M. Sznol, J. Low, Leuk. Res. 32 (2008) 71-77.

[90] F. Bacher, O. Dömötör, A. Chugunova, N.V. Nagy, L. Filipović, S. Radulović, E.A. Enyedy, V.B. Arion, Dalt. Trans. 44 (2015) 9071-9090.

[91] J. Ferlay, H.R. Shin, F. Bray, D. Forman, C. Mathers, D.M. Parkin, Int. J. Cancer 127 (2010) 2893-2917.

[92] B. O Karim, D.L. Huso, Am. J. Cancer Res. 3 (2013) 240-250.

[93] D.M. Muzny, M.N. Bainbridge, K. Chang, H.H. Dinh, J.A. Drummond, G. Fowler, et al. (The Cancer Genome Atlas Network), Nature 487 (2012) 330-337.

[94] S. Misale, R. Yaeger, S. Hobor, E. Scala, M. Janakiraman, D. Liska, et al., Nature 486 (2012) 532-536.

[95] A.M. Gouw, L.S. Eberlin, K. Margulis, D.K. Sullivan, G.G. Toal, L. Tong, R.N. Zare, D.W. Felsher, Proc. Natl. Acad. Sci. 114 (2017) 4300-4305.

[96] M. Morkel, P. Riemer, H. Bläker, C. Sers, Oncotarget 6 (2015) 20785-20800. 
[97] M. Lou, Q. Liu, G. Ren, J. Zeng, X. Xiang, Y. Ding, Q. Lin, T. Zhong, X. Liu, L. Zhu, H. Qi, J. Shen, H. Li, J. Shao, J. Biol. Chem. 292 (2017) 9136-9149.

[98] X. Zhou, X. Xu, J. Wang, J. Lin, W. Chen, Sci. Rep. 5 (2015) 12995.

[99] C.-K. Oh, S.J. Lee, S.-H. Park, Y. Moon, J. Biol. Chem. 291 (2016) 1017310183.

[100] M.A. Hussein, M.A. Iqbal, M. Asif, R.A. Haque, M.B.K. Ahamed, A.M.S.A. Majid, T.S. Guan, Phosphorus. Sulfur. Silicon Relat. Elem. 190 (2015) 14981508.

[101] S. Sandhaus, R. Taylor, T. Edwards, A. Huddleston, Y. Wooten, R. Venkatraman, R.T. Weber, A. González-Sarrías, P.M. Martin, P. Cag, Y.-C. TseDinh, S.J. Beebe, N. Seeram, A.A. Holder, Inorg. Chem. Commun. 64 (2016) 45-49.

[102] P. Gómez-Saiz, J. García-Tojal, M.A. Maestro, F.J. Arnaiz, T. Rojo, Inorg. Chem. 41 (2002) 1345-1347.

[103] A.G. Bingham, H. Bögge, A. Müler, E.W. Ainscough, A.M. Brodie, J. Chem. Soc., Dalton Trans. (1987) 493-499.

[104] P. Gómez-Saiz, J. García-Tojal, A. Mendia, L. Lezama, J.L. Pizarro, M.I. Arriortua, T. Rojo, Eur. J. Inorg. Chem. (2003) 518-527.

[105] P. Gómez-Saiz, R. Gil-García, M.A. Maestro, J.L. Pizarro, M.I. Arriortua, L. Lezama, T. Rojo, M. González-Álvarez, J. Borrás, J. García-Tojal, J. Inorg. Biochem. 102 (2008) 1910-1920.

[106] M. Herreros-Villanueva, P. Muñiz, C. García-Giron, M. Cavia-Saiz, M.J. Del Corral, J. Transl. Med. 8 (2010) 15

[107)] F.E. Anderson, C.J. Duca, J.V. Scudi, J. Am. Chem. Soc. 73 (1951) 4967-4968.

[108] D.X. West, G.A. Bain, R.I. Butcher, J.P. Jasinskin, R.Y. Pozniakiv, J. ValdésMartínez, R.A. Toscano, S. Hernández-Ortega, Polyhedron 15 (1996) 665-674..

[109] D.X. West, G.A. Bain, J.S. Saleda, A.E. Liberta, Transition Met. Chem. 16 (1991) 565-572.

[110] R. Noto, P. Lo Meo, M. Gruttadauria, G. Werber, J. Heterocyclic. Chem. 33 (1996) 863-872.

[111] WINEPR SimFonia v1.25, Bruker Analytische Messtecnik GmßH, 1996.

[112] A. Altomare, M.C. Burla, M. Camalli, G. L. Cascarano, C. Giacovazzo, A. Guagliardi, A.G.G. Moliterni, G. Polidori and R. Spagna, J. Appl. Crystallogr. 32 (1999) 115-119.

[113] G.M. Sheldrick, Acta Crystallogr. A64 (2008) 112-122.

[114] L.J. Farrugia, WINGX; J. Appl. Crystallogr. 45 (2012) 849-854.

[115] P. Twentyman, M. Luscombe. Brit. J. Cancer 56 (1987) 279-285.

[116] R.L. Levine, E.R. Stadtman, Exp. Gerontol. 36 (2001) 1495-1502.

[117] J.M. McCord, I. Fridowich, J. Biol. Chem. 243 (1968) 5753-5760.

[118] J. García-Tojal, J. García-Jaca, R. Cortés, T. Rojo, M.K. Urtiaga, M.I. Arriortua, Inorg. Chim. Acta 249 (1996) 25-32.

[119] P. Gómez-Saiz, R. Gil, M.A. Maestro, J.L. Pizarro, M.I. Arriortua, L. Lezama, T. Rojo, J. García-Tojal, Eur. J. Inorg. Chem. (2005) 3409-3413, and references therein.

[120] R. Gil-García, R. Fraile, B. Donnadieu, G. Madariaga, V. Januskaitis, J. Rovira, L. González, J. Borrás, F.J. Arnáiz, J. García-Tojal, New J. Chem. 37 (2013) 3568-3580.

[121] A.W. Addison, T.N. Rao, J. Reedijk, G.C. Verschoor, J. Chem. Soc., Dalton Trans. (1984) 1349-1356. 
[122] Y.M. Chumakov, V.I. Tsapkov, E. Jeanneau, N.N. Bairac, G. Bocelli, D. Poirier, J. Roy, A.P. Gulea, Crystallogr. Reports. 53 (2008) 786-792.

[123] D. Dragancea, A.W. Addison, M. Zeller, L.K. Thompson, D. Hoole, M.D. Revenco, A.D. Hunter, Eur. J. Inorg. Chem. (2008) 2530-2536.

[124] D. Dragancea, V.B. Arion, S. Shova, E. Rentschler, N.V. Gerbeleu, Angew. Chem. Int. Ed. 44 (2005) 7938-7942.

[125] W.-S. Wu, W.-D. Cheng, D.-S. Wu, H. Zhang, Y.-J. Gong, Y. Lu, Inorg. Chem. Commun. 9 (2006) 559-562.

[126] R. Gil-García, P. Gómez-Saiz, V. Díez-Gómez, G. Madariaga, M. Insausti, L. Lezama, J.V. Cuevas, J. García-Tojal, Polyhedron 81 (2014) 675-686.

[127] J.C. Bonner, M.E. Fisher, Phys. Rev. A 135 (1964) 640-658.

[128] M.K. Urtiaga, M.I. Arriortua, J. Garcia-Tojal, T. Rojo, Acta Crystallogr. C51 (1995) 2172-2174.

[129] T.S. Lobana, R. Sharma, A. Castiñeiras, R. Jay, Z. Anorg. Allg. Chem. 636 (2010) 2698-2703.

[130] D. Dekanski, T. Todorović, D. Mitić, N. Filipović, N. Polović, K.J. Anđelković, Serb. Chem. Soc. 8 (2013) 1503-1512.

[131] N. Filipović, N. Polović, B. Rašković, S. Misirlić-Denčić, M. Dulović, M. Savić, M. Nikšić, D. Mitić, K. Anđelković, T. Todorović, Monatsh. Chem. 145 (2014) 1089-1099.

[132] Z. Al-Eisawi, C. Stefani, P.J. Jansson, A. Arvind, P.C. Sharpe, M.T. Basha, G.M. Iskander, N. Kumar, Z. Kovacevic, D.J. Lane, S. Sahni, P.V. Bernhardt, D.R. Richardson, D.S. Kalinowski, J. Med. Chem. 59 (2016) 294-312.

[133] J. Li, L.M. Zheng, I. King, T.W. Doyle, S.H. Chen, Curr. Med. Chem. 8 (2001) 121-133.

[134] A. Sirbu, O. Palamarciuc, M.V. Babak, .J.M. Lim, K. Ohui, E.A. Enyedy, S. Shova, D. Darvasiová, P. Rapta, W.H. Ang, V.B. Arion. Dalton Trans. 46 (2017) 3833-3847.

[135] P.D. Ray, B.W. Huang, Y. Tsuji, Cell Signal 24 (2012) 981-990.

[136] M. Valko, D. Leibfritz, J. Moncol, M.T. Cronin, M. Mazur, J. Telser, Int. J. Biochem. Cell Biol. 39 (2007) 44-84.

[137] A.T. Dharmaraja, J. Med. Chem. 60 (2017) 3221-3240.

[138] D. Trachootham, J. Alexandre, P. Huang, Nat. Rev. Drug Discov. 8 (2009) 579-591.

[139] J.M. Hansen, H. Zhang, D.P. Jones, Free Radical Biol. Med. 40 (2006) 138-145. 
Table 1. Crystallographic data for 1.

\begin{tabular}{|c|c|}
\hline Empirical formula & $\mathrm{C}_{14} \mathrm{H}_{14} \mathrm{Cu}_{2} \mathrm{~N}_{10} \mathrm{O}_{6} \mathrm{~S}_{2}$ \\
\hline Formula weight & 609.55 \\
\hline Temperature & 293(2) K \\
\hline Wavelength & $0.71069 \AA$ \\
\hline Crystal system & Monoclinic \\
\hline Space group & $\mathrm{P} 2{ }_{1}$ \\
\hline \multirow[t]{3}{*}{ Unit cell dimensions } & $\mathrm{a}=7.472(2) \AA \quad \alpha=90.00^{\circ}$ \\
\hline & $\mathrm{b}=14.967(5) \AA \quad \beta=90.07(2)^{\circ}$ \\
\hline & $\mathrm{c}=9.510(3) \AA \quad \gamma=90.00^{\circ}$ \\
\hline Volume & $1063.5(6) \AA^{3}$ \\
\hline $\mathrm{Z}$ & 2 \\
\hline Density (calculated) & $1.903 \mathrm{Mg} / \mathrm{m}^{3}$ \\
\hline Absorption coefficient & $2.254 \mathrm{~mm}^{-1}$ \\
\hline $\mathrm{F}(000)$ & 612 \\
\hline Crystal size & $0.081 \times 0.055 \times 0.004 \mathrm{~mm}$ \\
\hline$\theta$ range for data collection & 2.141 to $26.747^{\circ}$ \\
\hline Index ranges & $-9 \leq \mathrm{h} \leq 9,-18 \leq \mathrm{k} \leq 18,-12 \leq 1 \leq 12$ \\
\hline Reflections collected & 11139 \\
\hline Independent reflections & $4126\left[\mathrm{R}_{\mathrm{int}}=0.1787\right]$ \\
\hline Absorption correction & Analytical gaussian \\
\hline Data / restraints / parameters & 4126 / 343 / 336 \\
\hline Goodness-of-fit on $\mathrm{F}^{2}$ & $S=0.639$ \\
\hline $\mathrm{R}$ indices $[\mathrm{I}>2 \sigma(\mathrm{I})]$ & $\mathrm{R}_{1}=0.0591, \mathrm{wR}_{2}=0.1301$ \\
\hline R indices (for all 4126 data) & $\mathrm{R}_{1}=0.245, \mathrm{wR}_{2}=0.1313$ \\
\hline Largest diff. peak and hole & 0.45 and $-0.41 \mathrm{e}^{-3}$ \\
\hline
\end{tabular}


Table 2. Selected bonds $(\AA)$ and angles $\left({ }^{\circ}\right)$ of 1 .

\begin{tabular}{llllll}
\hline \multicolumn{1}{c}{$(1)$} & \multicolumn{1}{c}{$(2)$} & & $(1)$ & $(2)$ \\
\hline $\mathrm{Cu}-\mathrm{S}$ & $2.242(7)$ & $2.256(7)$ & $\mathrm{N} 4-\mathrm{C} 7$ & $1.30(3)$ & $1.34(2)$ \\
$\mathrm{Cu}-\mathrm{N} 2$ & $1.962(17)$ & $1.948(16)$ & $\mathrm{C} 7-\mathrm{N} 3$ & $1.35(3)$ & $1.37(2)$ \\
$\mathrm{Cu}-\mathrm{N} 3$ & $2.002(14)$ & $2.001(16)$ & $\mathrm{N} 2-\mathrm{N} 3$ & $1.371(19)$ & $1.357(16)$ \\
$\mathrm{Cu}-\mathrm{N} 1$ & $1.997(18)$ & $1.950(16)$ & $\mathrm{N} 2-\mathrm{C} 6$ & $1.29(3)$ & $1.27(2)$ \\
$\mathrm{Cu}-\mathrm{O} 31 / 32 \mathrm{~A}$ & $2.75(2)$ & $2.47(3)$ & $\mathrm{S}-\mathrm{C} 7$ & $1.74(2)$ & $1.73(2)$ \\
$\mathrm{Cu}-\mathrm{O} 21 / 22 \mathrm{~B}$ & $2.86(2)$ & $2.51(4)$ & & & \\
S-Cu-N2 & $83.9(6)$ & $83.6(6)$ & $\mathrm{N} 2-\mathrm{Cu}-\mathrm{N} 3$ & $177.9(7)$ & $168.6(9)$ \\
$\mathrm{S}-\mathrm{Cu}-\mathrm{N} 3$ & $96.2(6)$ & $95.3(5)$ & $\mathrm{N} 2-\mathrm{Cu}-\mathrm{N} 1$ & $83.3(8)$ & $81.6(7)$ \\
$\mathrm{S}-\mathrm{Cu}-\mathrm{N} 1$ & $165.4(5)$ & $163.1(5)$ & $\mathrm{N} 3-\mathrm{Cu}-\mathrm{N} 1$ & $96.9(7)$ & $97.7(7)$ \\
\hline
\end{tabular}


Table 3. $\mathrm{IC}_{50}$ values of TSCs and their $\mathrm{Cu}^{\mathrm{II}}$ complexes in SW480 and HT29 cell lines.

\begin{tabular}{|c|c|c|}
\hline & \multicolumn{2}{|c|}{$\mathrm{IC}_{50}(\mu \mathrm{M})$} \\
\hline & SW480 & HT-29 \\
\hline HPTSC & $26.8 \pm 4.4^{b}$ & $47.2 \pm 5.49^{b}$ \\
\hline HPTSC-Cu ${ }^{I I}$ & $5.48 \pm 0.79^{\mathrm{a}}$ & $5.49 \pm 0.20^{\mathrm{a}}$ \\
\hline HPTSC* & $29.6 \pm 8.17^{b}$ & $75 \pm 14.1^{\mathrm{c}}$ \\
\hline HPTSC*-Cu$^{\text {II }}$ & $3.67 \pm 0.14^{\mathrm{a}}$ & $3.70 \pm 0.23^{\mathrm{a}}$ \\
\hline
\end{tabular}

$\mathrm{IC}_{50}(50 \%$ inhibitory concentrations) values of free thiosemicarbazones (HPTSC and HPTSC*) and their complexes. Data expressed in $\mu \mathrm{M}$ as mean values \pm standard deviation $(n=3)$ 


\section{FIGURE/SCHEME LEGENDS}

Scheme 1. Structures of thiosemicarbazones discussed in the Introduction. The present manuscript deals with HPTSC and HPTSC* .

Figure 1. View along the [010] direction perpendicular to the layers in 1.

Figure 2. ORTEP drawing of the tetragonal elongated environment around Cu1. Thermal ellipsoids are drawn at the $50 \%$ probability level. The labeling scheme of the thiosemicarbazone adds " 1 ” after the corresponding usual notation by the authors (e.g. N13 = N3, etc...).

Figure 3. ORTEP drawing of the square pyramidal polyhedron of $\mathrm{Cu} 2$. Thermal ellipsoids are drawn at the $50 \%$ probability level. Note the disorder in the oxygen atoms of the nitrato ligand. The labels of the thiosemicarbazone start by “2” in this case (e.g. N23 = N3, etc...).

Figure 4. Powder Q-band EPR spectra of compound 1. The fit is given as a dotted red line.

Figure 5. Graphics of $\chi$ vs $T$ (hollow spheres) and $\chi T$ vs $T$ (black spheres) for compound 1 . The fits are given as continuous lines.

Figure 6. SOD activity (U/mg prot) of SW480 and HT29 cells treated with the HPTSC and HPTSC* ligands and their complexes. Data are expressed as mean values \pm standard deviation $(n=3)$. Significant differences $(\mathrm{p}<0.05)$ among the treatments are expressed in Roman (SW480) and Greek letters (HT29).

Figure 7. Carbonyl groups of SW480 and HT29 cells treated with the HPTSC and HPTSC* ligands and their complexes. Data are expressed as mean values \pm 
standard deviation $(\mathrm{n}=3)$. Significant differences $(\mathrm{p}<0.05)$ among the treatments are expressed in Roman (SW480) and Greek letters (HT29).

Figure 8. Intracellular redox status (GSH/GSSG ratio) of SW480 and HT29 cells treated with the HPTSC and HPTSC* ligands and their complexes. Data are expressed as mean values \pm standard deviation $(n=3)$. Significant differences $(\mathrm{p}<0.05)$ among the treatments are expressed in Roman (SW480) and Greek letters (HT29). 


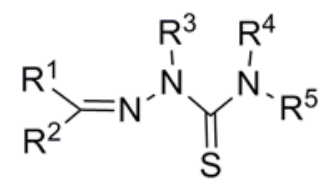

Thiosemicarbazones

\begin{tabular}{|c|c|c|c|c|c|}
\hline & $\mathrm{R}^{1}$ & $\mathrm{R}^{2}$ & $\mathrm{R}^{3}$ & $\mathrm{R}^{4}$ & $\mathrm{R}^{5}$ \\
\hline HPTSC & $\mathrm{H}$ & & $\mathrm{H}$ & $\mathrm{H}$ & $\mathrm{H}$ \\
\hline HPTSC* & $\mathrm{H}$ & & $\mathrm{H}$ & $\mathrm{CH}_{3}$ & $\mathrm{H}$ \\
\hline HTTSC* & $\mathrm{H}$ & & $\mathrm{H}$ & $\mathrm{H}$ & $\mathrm{H}$ \\
\hline Triapine $^{\circledR}$ & $\mathrm{H}$ & & $\mathrm{H}$ & $\mathrm{H}$ & $\mathrm{H}$ \\
\hline 5OHPTSC & $\mathrm{H}$ & & $\mathrm{H}$ & $\mathrm{H}$ & $\mathrm{H}$ \\
\hline $\mathrm{Dp} 44 \mathrm{mt}$ & & & $\mathrm{H}$ & $\mathrm{CH}_{3}$ & $\mathrm{CH}_{3}$ \\
\hline
\end{tabular}

Scheme 1. 


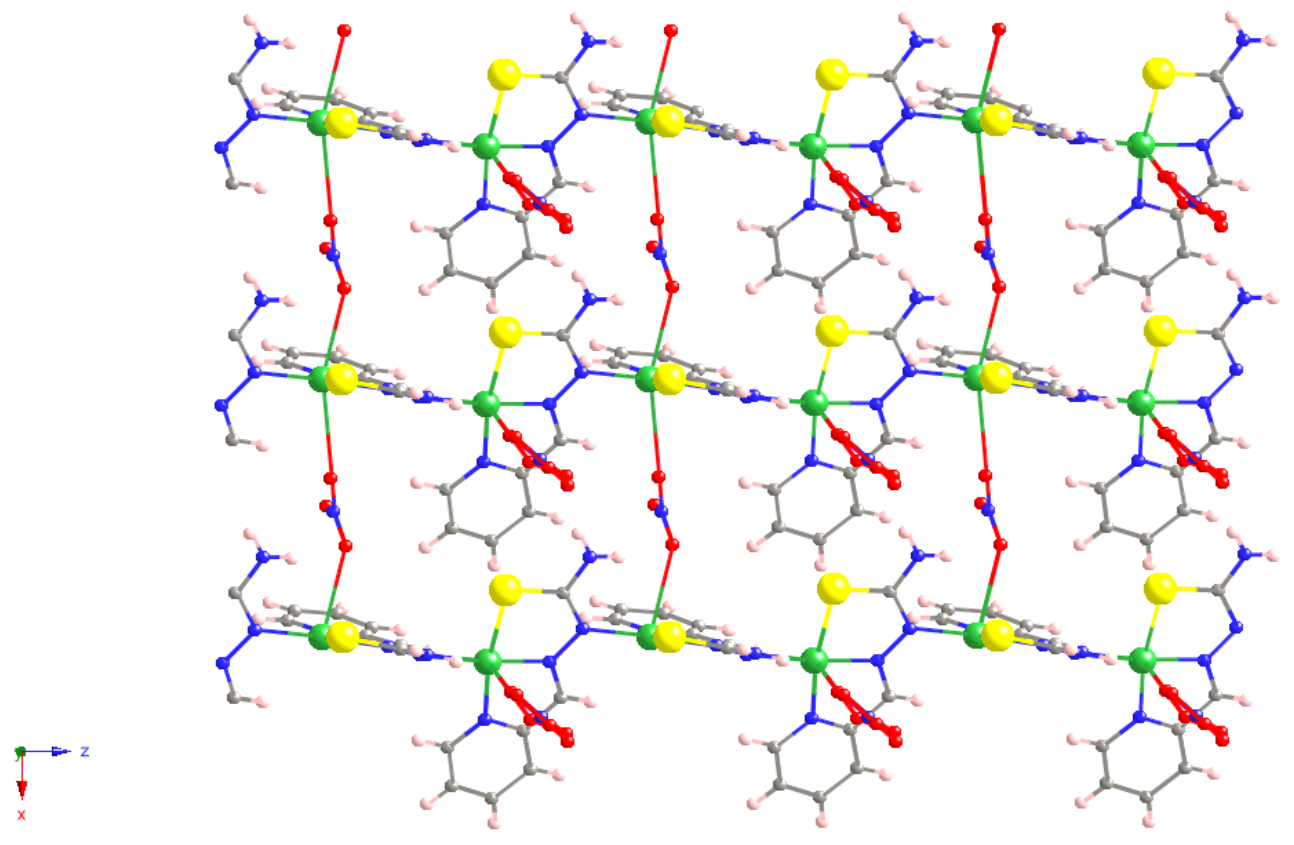

Figure 1 


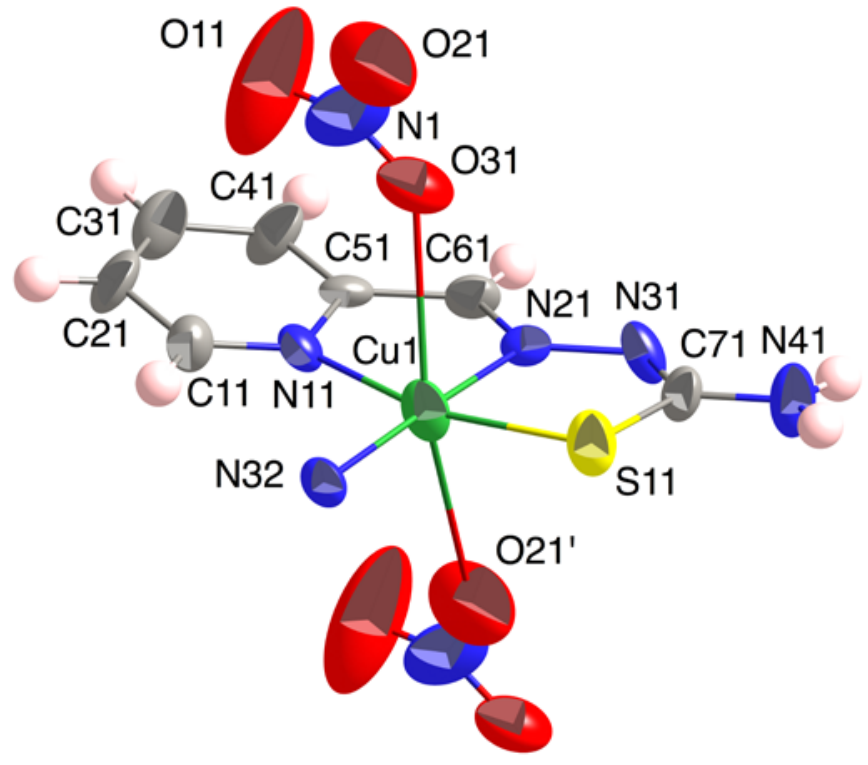

Figure 2

34 


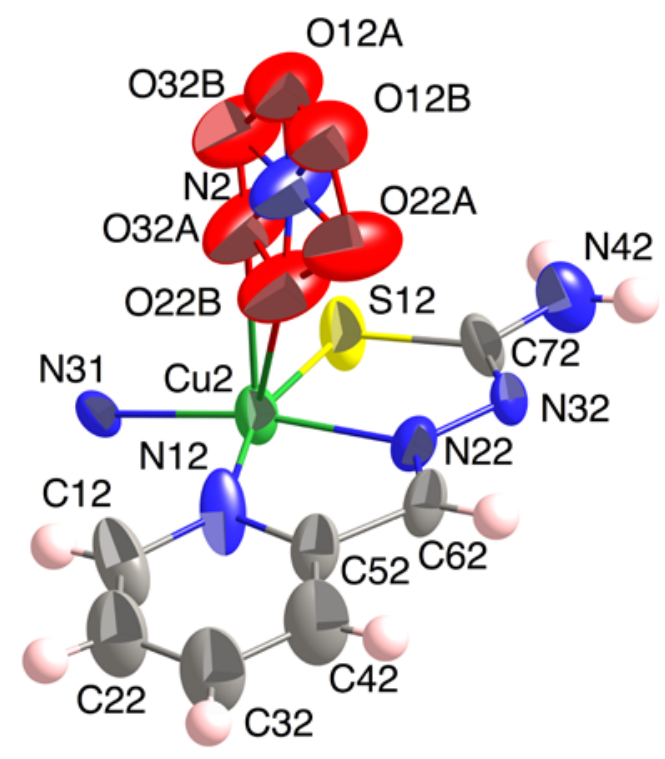

Figure 3 


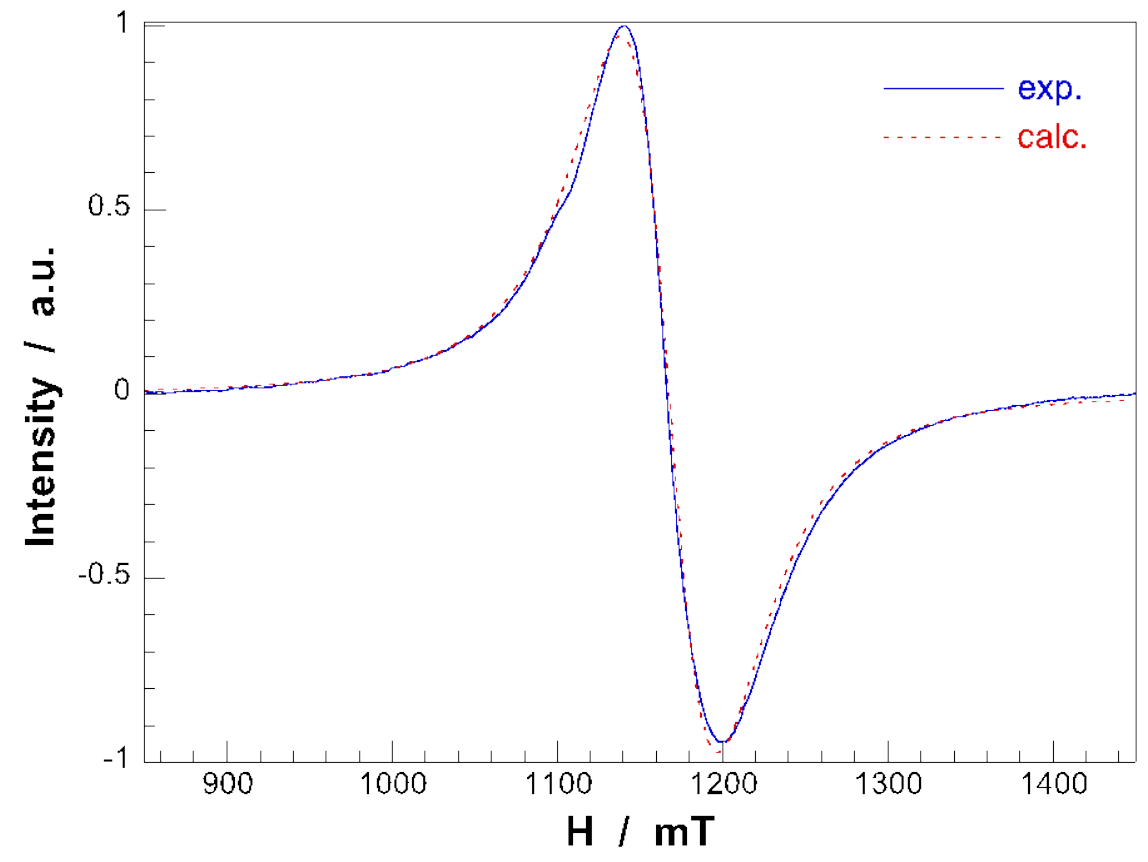

Figure 4 


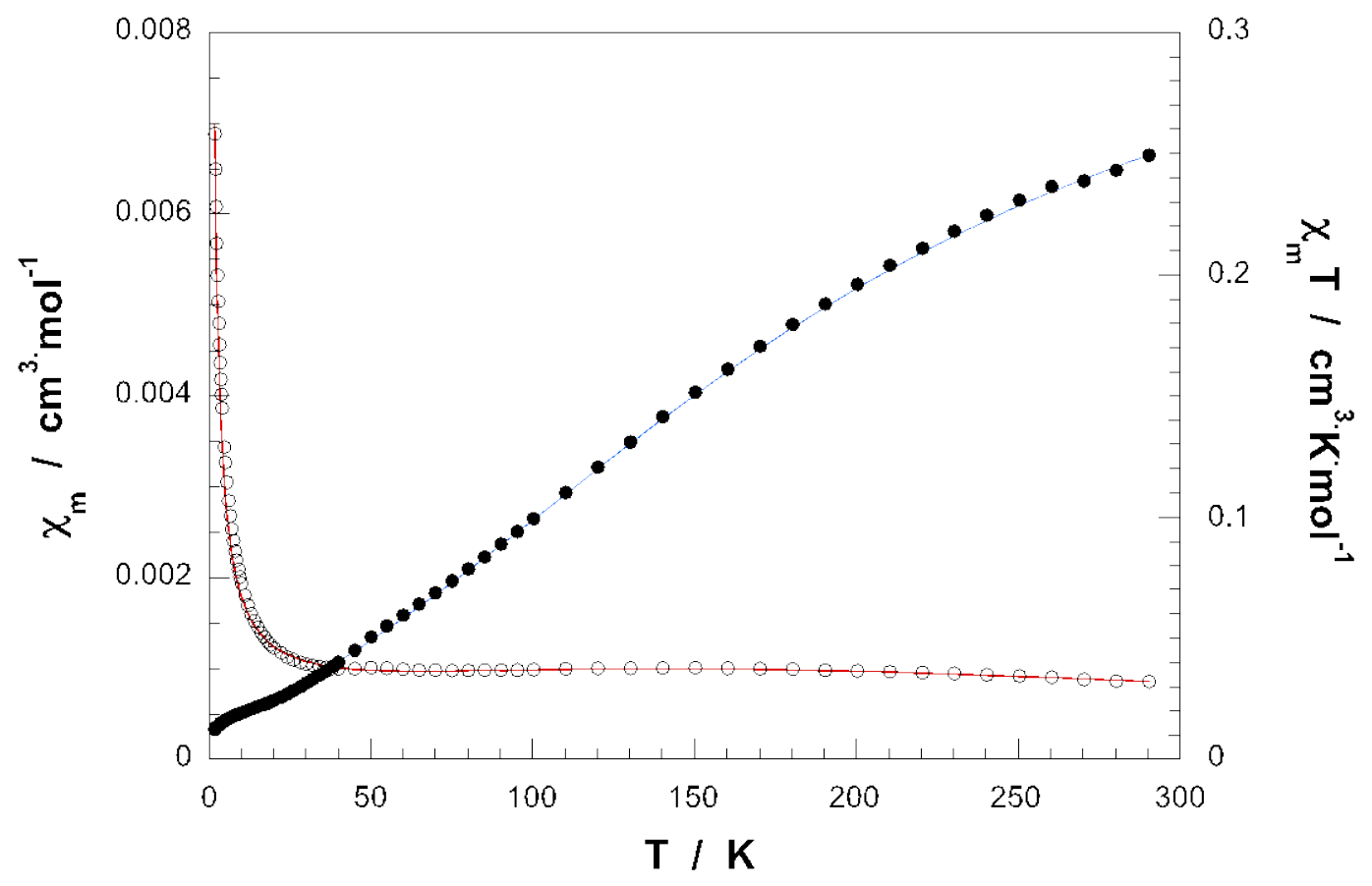

Figure 5 


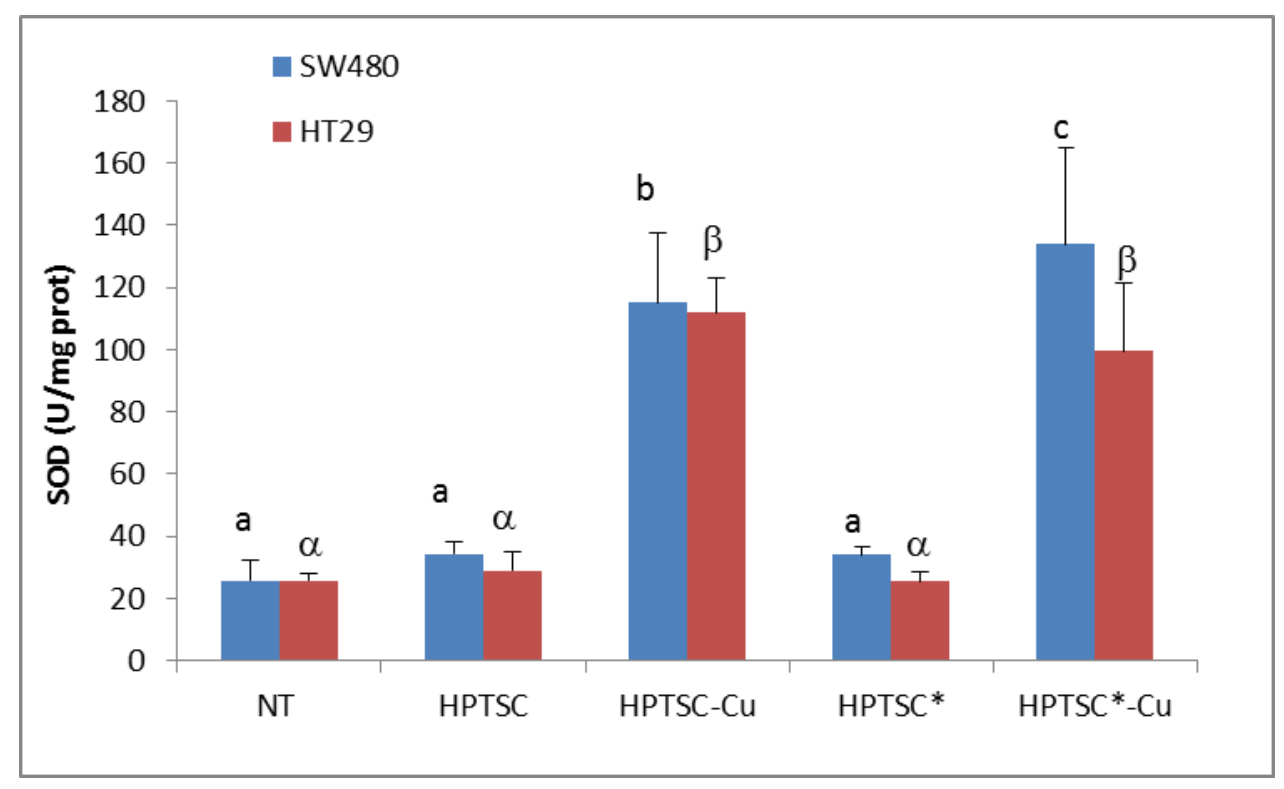

Figure 6 


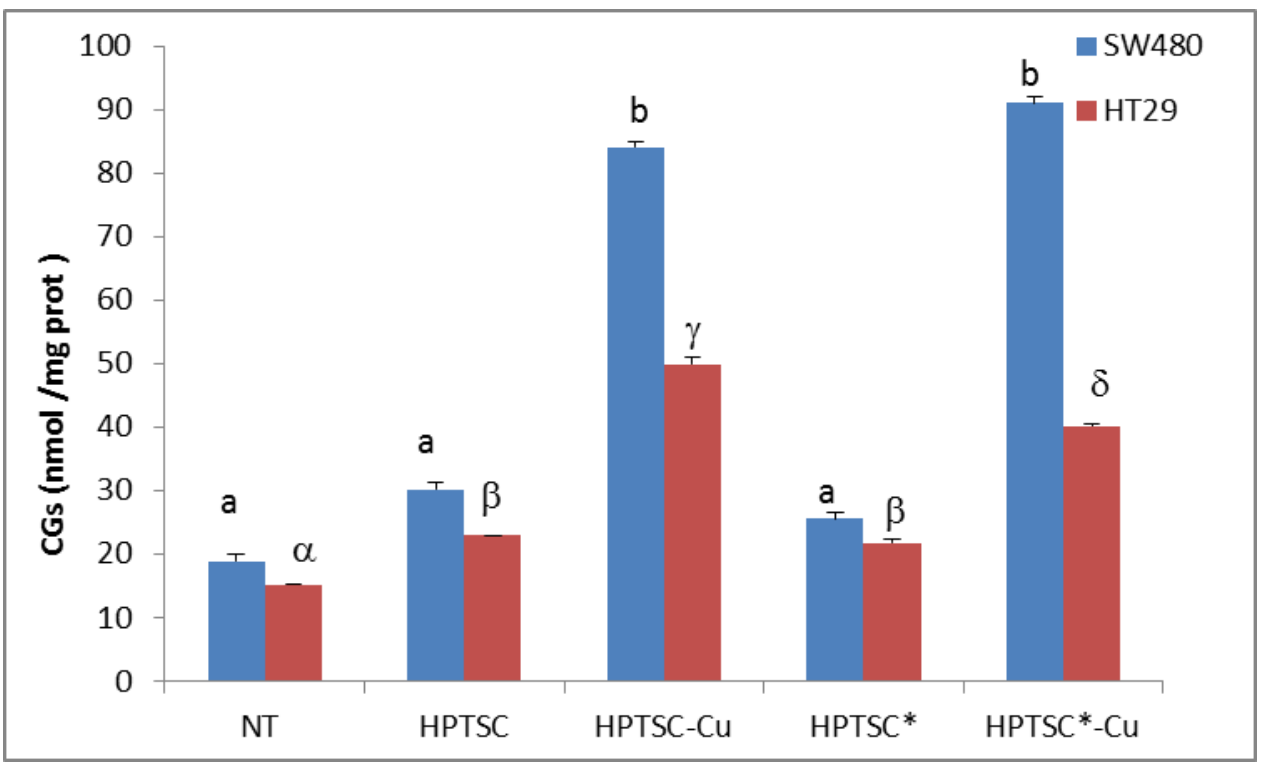

Figure 7 


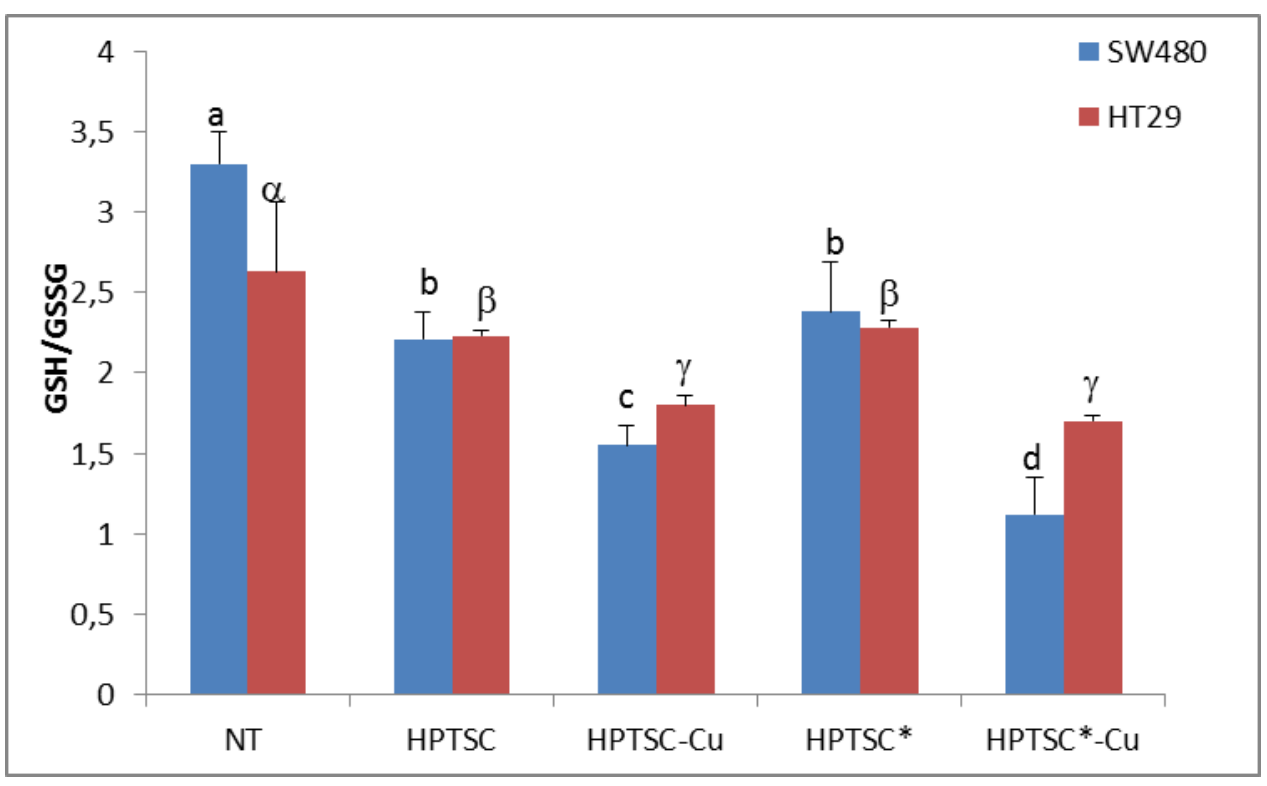

Figure 8 